\title{
SOLUBILIZAÇÃO DE UMA FLUORAPATITA POR FUNGOS \\ FILAMENTOSOS EM MEIO SINTÉTICO, E EM VINHAÇA \\ NATURAL E ESTERILIZADA
}

PAULO ROBSON DE SOUZA

Biólogo

Orientadora: Prof ${ }^{a}$ Dra. EIKE J. B.N. CARDOSO

Dissertação apresentada à Escola

Superior de Agricultura "Luiz de

Queiroz", da Universidade de São

Paulo, para obtenção do título de

Mestre em Agronomia, Área de

Concentração: Microbiologia

Agrícola.

P I R A C I C A B A

Estado de São Paulo - Brasil

Novembro - 1989 
Ficha catalográfica preparada pela Seção de Livros da Divisão de Biblioteca e Documentação - PCAP/USP

Souza, Paulo Robson de

S729s Solubilização de uma fluorapatita por fungos filamentosos em meio sintético, e em vinhaça natural e es terilizada. Piracicaba, 1989.

$86 \mathrm{p}$.

Diss. (Mestre) - ESALQ

Bibliografia.

1. Fluorapatita - Solubilização microbiana 2. Fungo - Meio de cultura 3. Fungo - Solubilidade 4. Solo Microbiologia 5. Vinhaça como meio de cultura I. Escola Superior de Agricultura Luiz de Queiroz, Píracica ba.

CDD $\quad 631.46$ 


\section{SOLUBILIZAÇÃo DE UMA FLUORAPATITA POR FUNGOS FILAMENTOSOS EM MEIO SINTÉTICO, E EM VINHAÇA NATURAL E ESTERILIZADA}

PAULO ROBSON DE SOUZA

Aprovado en 28/12/1989

Comissão Julgadora:

Prof. Dr. Francisco A. F. de Mello

- ESALQNUSP

Prof. Dr. Jorge de Castro Kiehl

- ESALQ/USP

Prof ${ }^{a}$. Dr. Aline A. Pizzirani-Kleiner

- ESALQ/USP

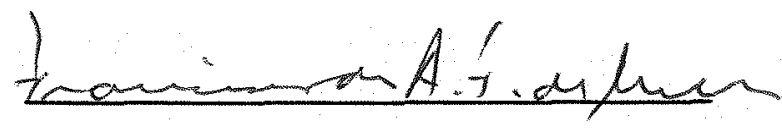

Prof.Dr. FRANCISCO A.F. DE MELLO Substituindo a orientadora, Profa.Dra. ELKE J.B.N. CARDOSO 
Lo meu pai e minhas mãeo,

Beth e rassos filhatinhos,

aos que lutam pra viver...

que, pela amar e carinho,

me ensinaram a dissaher

as pedras do meu camirho. 
Eu não tenho filosofia: tenho sentidos...

Se falo na Natureza não é porque saiba o que ela é, Mas porque a amo, e amo-a por isso,

Porque quem ama nunca sabe o que ama

Nem sabe por que ama, nem o que é amar...

Amar é a eterna inocência,

E a única inocência não pensar...

Fernando Pessoa

(O Guardador de Rebanhos - fragmento) 
AGRADECIMENTOS

- A Dra. Elke J. B. N. Cardoso, pela preciosa orientação e pelo apoio, dado em forma de amizade.

- Ao Prof. Márcio Lambais, pela co-orientação e estímulo.

- Aos amigos Adriana Parada Dias da Silveira e Vanderlei Antunes, pela dedicada colaboração nos momentos mais dificeis, fundamental à conclusão deste trabalho.

- Ao Dr. Jorge Kiehl, por preciosas sugestões à redação final.

- Ao Dr. Francisco de A. F. de Mello, pelo apoio.

- Ao Prof. Gerd Sparovek, pela análise cristalográfica.

- Ao Dr. Valdomiro Bittencourt, pelas sugestões que muito auxiliaram na escolha dos objetivos deste trabalho.

- Ao Dr. Joaquim Albenísio da Silveira e pessoal do Laboratório de Bioquímica do CENA, pelo auxilio nas análises de açúcares redutores.

- Aos Professores Marco Aurélio M. Rodrigues, Yvelise Possiede e Hélio Augusto Godoy de Souza, pelo apoio às nossas atividades na UFMS.

- À Dra. Sandra S. B. Trufen, do Instituto de Botânica, pela identificação dos fungos.

- Ao CNPq e PICD-CAPES, pela concessão de bolsa. 
- Ao Centro de Informática na Agricultura da ESALQ, à Eliane Zaidan Silvestre, aos técnicos do LSG/ESALQ Denise Colombo, Luis Fernando Baldesin, Marley R. Perez e colegas, pela presteza e eficiência no desempenho de suas atribuições.

- Entre outros agradecemos aos amigos Almiro Paixão, Edgar M. Brandão, Eleni Gomes, Genovefa Peisino, Helaine Carrer, Luzia Paccola, Lygia Veiga Carvalho, Maria do Carmo Esteves, Marcelo C. Jahnel, Rosângela B. Navarro, Sérgio Duarte e Shirley Brunelli, cuja convivência muito contribuiu para o alcance de nossos objetivos. 


\section{SUMÁRIO}

\section{Página}

LISTA DE FIGURAS

LISTA DE TABELAS

1. INTRODUÇÃO $\ldots \ldots \ldots \ldots \ldots \ldots \ldots \ldots \ldots \ldots \ldots \ldots \ldots \ldots \ldots \ldots \ldots$

2. REVISÃo DE LITERATURA $\ldots \ldots \ldots \ldots \ldots \ldots \ldots \ldots \ldots \ldots \ldots \ldots \ldots$

2.1. o fósforo no solo .................. 3

2.2. Dissolução de fosfatos por microrganismos do solo $\ldots \ldots \ldots \ldots \ldots \ldots \ldots \ldots \ldots \ldots \ldots \ldots$

2.3. O emprego de vinhaça como substrato para solubilização de fosfatos ............. 11

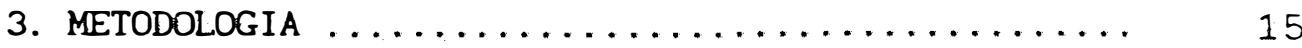

3.1. Local de condução dos experimentos ........ 15

3.2. Fosfato de rocha utilizado ............. 15

3.3. Microrganismos utilizados e isolamento ...... 16

3.4. Manutenção de cultura axênica ........... 17

3.5. Preparo do inóculo ............... 18

3.6. Condições de cultivo $\ldots \ldots \ldots \ldots \ldots \ldots \ldots \ldots \ldots$

3.7. Filtração $\ldots \ldots \ldots \ldots \ldots \ldots \ldots \ldots \ldots \ldots \ldots \ldots$

3.8. Determinação do fósforo solubilizado ....... 19 
3.9. Determinação do nitrogênio, residuo orgânico, carbono orgânico e residuo mineral total ... 20

3.10. Leitura dos valores de $\mathrm{pH} \ldots \ldots \ldots \ldots \ldots \ldots . \ldots 20$

3.11. Determinação da biomassa microbiana........ 21

3.12. Análise estatística $\ldots \ldots \ldots \ldots \ldots \ldots \ldots \ldots \ldots$

3.13. Seleção de microrganismos solubilizadores de fosfato - EXPERIMENTO $1 \ldots \ldots \ldots \ldots \ldots \ldots .21$

3.14. Efeito de fungos e do $\mathrm{H}_{2} \mathrm{SO}_{4}$ na composição mineralógica e na solubilização da fluorapatita - EXPERIMENTO $2 \ldots \ldots \ldots \ldots \ldots \ldots \ldots \ldots \ldots$

3.15. Efeito de dose de fosfato, fungo e tempo de cultivo na solubilização da fluorapatita bruta - EXPERIMENTO $3 \ldots \ldots \ldots \ldots \ldots \ldots$

3.16. Solubilização biológica do fosfato, aplicado doses crescentes, em diferentes períodos de cultivo, utilizando-se vinhaça esterilizada - EXPERIMENTO $4 \ldots \ldots \ldots$

3.17. Mineralização do fósforo orgânico e solubilização de fosfato bruto em vinhaça naturàl, em ausência e presença de fungos selecionados EXPERIMENTO $5 \ldots \ldots \ldots \ldots \ldots \ldots \ldots \ldots$

3.18. Solubilizaçäo do fosfato bruto utilizando-se fungos selecionados, vinhaça natural e esterilizada - EXPERIMENTO $6 \ldots \ldots \ldots \ldots$ 
4. RESUltados E DISCUSSÃo $\ldots \ldots \ldots \ldots \ldots \ldots \ldots$

4.1. Seleção de microrganismos solubilizadores de fosfato - EXPERIMENTo $1 \ldots \ldots \ldots \ldots \ldots$

4.2. Efeito de fungos e do $\mathrm{H}_{2} \mathrm{SO}_{4}$ na composição mineralógica e na solubilização da fluorapatita - EXPERIMENTO $2 \ldots \ldots \ldots \ldots \ldots$

4.3. Efeito de dose de fosfato, fungo e tempo de cultivo na solubilização da fluorapatita bruta - EXPERIMENTO $3 \ldots \ldots \ldots \ldots \ldots$

4.4. Solubilização biológica do fosfato, aplicado em doses crescentes, em diferentes períodos de cultivo, utilizando-se vinhaça esterilizada - EXPERIMENTO $4 \ldots \ldots \ldots \ldots \ldots$

4.5. Mineralização do fosfato orgânico e solubilização de fosfato bruto em vinhaça natural; em ausência e presença de fungos selecionados EXPERIMENTO $5 \ldots \ldots \ldots \ldots \ldots \ldots \ldots$

4.6. Solubilização do fosfato bruto utilizando-se vinhaça natural e esterilizada - EXPERIMENTO

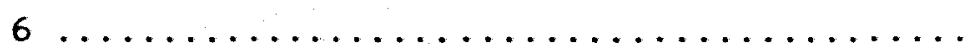

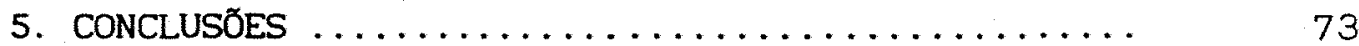

6. REFERENCIAS BIBLIOGRÁFICAS $\ldots \ldots \ldots \ldots \ldots \ldots \ldots$ 
FIGURA 01 - Efeito dos fungos 09 e 60 (A. niger) sobre a solubilização da fluorapatita com diferentes graus de solubilização em $\mathrm{H}_{2 \mathrm{SO}} 4$ concentrado $\ldots \ldots \ldots \ldots \ldots \ldots$

FIGURA 02 - Variação do pH em cinco culturas fúngicas e no controle em relação ao grau de solubilização da fluorapatita por $\mathrm{H}_{2} \mathrm{SO}_{4}$.

FIGURA 03 - Concentração de açúcares redutores nos filtrados do controle e fungos 25,60 e 09, cultivados sob diferentes graus de solubilização da fluorapatita por $\mathrm{H}_{2 \mathrm{SO}} \ldots \ldots \ldots \ldots \ldots \ldots \ldots \ldots$ 
FIGURA 04 - Variação da concentração de açúcares redutores do filtrado do controle e das culturas $25,60,09,28$ e 34 , em relação ao grau de solubilização da fluorapatita por $\mathrm{H}_{2} \mathrm{SO}_{4} \ldots \ldots \ldots \ldots \ldots \ldots \ldots \ldots \ldots \ldots$

FIGURA 05 - Fósforo solubilizado pelos fugos 34 (A. niger) e 25 (Penicillium sp), em relação ao tempo de cultivo..........

FIGURA 06 - Variação do pH nas culturas 25, 34 e no controle, em relação ao tempo de

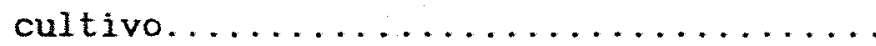

FIGURA 7 - Fósforo solubilizado pelos fungos 60,25 e 34, en relação ao tempo de cultivo..................... 
TABELA 01 - Análise dos teores de $\mathrm{P} 205$ e valores de $\mathrm{pH}$ dos fosfatos natural e parcialmente solubilizados em $\mathrm{H}_{2} \mathrm{SO}_{4} \ldots \ldots \ldots \ldots \ldots \ldots$

TABELA 02 - Análise da variância do fósforo solubilizado, pH e bíomassa das culturas de micro-

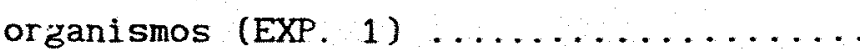

TABELA 03 - Teste de Tukey para as médias dos tratamentos, variáveis fósforo solubilizado , pH e biomassa (no de repetições $=3$ )

TABELA 04 - Análise da variância para fósforo solubilizado, $\mathrm{pH}$ e açúcares redutores.

TABELA 05 - Teores de fósforo solubilizado por diferentes fungos a partir de fluorapatita com diversos graus de solubilização por $\mathrm{H}_{2} \mathrm{SO}_{4}$ (média de 3 repetições). 
TABELA 06 - Valores de pH do filtrado, obtidos pela inoculação de diferentes fungos, empregando-se fluorapatita com diferentes graus de solubilização em $\mathrm{H}_{2} \mathrm{SO}_{4}$ concentrado (média de 3 repetíções).........

TABELA 07 - Concentração de açúcares redutores (mg/ml) do filtrado de cinco fungos, cultivados sob diversos graus de solubilização da fluorapatita por $\mathrm{H}_{2} \mathrm{SO}_{4}$ (média de 3 repetições)...

TABELA 08 - Análise cristalográfica da fluorapatita bruta parcialmente solubilizada por $A$, niger (cultura 34 ) e por $\mathrm{H}_{2} \mathrm{SO}_{4} \ldots \ldots \ldots$

TABELA 09 - Análise da variância para fósforo solubilizado, pH e biomassa (EXP. 3) ........

TABELA 10 - Teores de fósforo solubilizado por fungos (mg/l) em relação ao tempo de coleta e à dose de fósforo utilizada (média de 3 re-

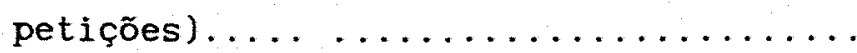

TABELA 11 - Análise da variância para fósforo solubi-

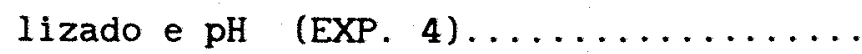


TABELA 12 - Teores de fósforo solubilizado por fungos (mg/l) em diversos tempos de cultivo e doses de fosfino (média de 3 repetições).

TABELA 13 - Análise da variância para fósforo solubi1 izado e $\mathrm{pH}(\mathrm{EXP} .5) \ldots \ldots \ldots \ldots \ldots \ldots$

TABELA 14 - Efeito da introdução de fungos selecionados e fluorapatita sobre os teores de fósforo solubilizado e valores de $\mathrm{pH}$ da vinhaça natural (média de 3 repetições).

TABELA 15 - Análise da variância para fósforo solubi-

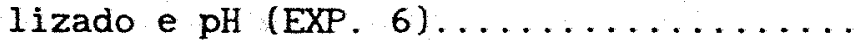

TABELA 16 - Efeito da introdução de fungos selecionados sobre a solubilização de fluorapatita e pH em vinhaça natural e esterilizada (média de 3 e 5 repetições)....... 
SOLUBILIZAÇÃO DE UMA FLUORAPATITA POR FUNGOS

FILAMENTOSOS EM MEIO SINTÉTICO, E EM VINHAÇA

NATURAL E ESTERILIZADA

Autor: PAULO ROBSON DE SOUZA

Orientadora: PROF ${ }^{\star}$ DRA. ELKE JURANDY BRAN NOGUEIRA CARDOSO

RESUMO

Foram realizados seis experimentos in vitro com o objetivo de avaliar a eficiência de diversos microrganismos em solubilizar uma fluorapatita proveniente de Catalão, Goiás. Também foram avaliados os efeitos de doses de fluorapatita, do tempo de cultivo e da solubilização parcial da fluorapatita com ácido sulfúrico, sobre a solubilização biológica do fosfato de rocha. 0 estudo foi realizado à temperatura ambiente utilizando-se uma solução de glicose com nutrientes minerais ou vinhaça esterilizada e não esterilizada como meios de culturas.

Em todos os experimentos o meio de cultura foi filtrado para determinação do teor de fósforo solubilizado e do $\mathrm{pH}$. Em alguns, foram determinados ainda os teores de açúcares redutores no filtrado e a produção de 
biomassa microbiana. Algumas amostras de fluorapatita foram submetidas à análise cristalográfica por difração de Raios-X.

Seis culturas de fungos filamentos foram selecionadas por terem apresentado elevado poder de solubilização em melo contendo glicose e nutrientes. Destas, duas culturas de Aspergillus niger foram mais eficientes em solubilizar a fluorapatita em todas as condições de cultivo estudadas.

Nos cultivos com prazos superiores a 21 dias ocorreram os maiores teores de fósforo solúvel. Aspergillus niger apresentou maior solubilização em baixas doses, e Penicillium sp em doses elevadas. Correlações entre pH e fósforo solubilizado dependeram dos meios de cultivo empregados.

Não houve mudança na composição mineralógica da fluorapatita devido ao ataque fúngico, embora Aspergillus niger tenha solubilizado uma quantidade de fósforo equivalente à encontrada em fluorapatita $25 \%$ solubilizada por $\mathrm{H}_{2} \mathrm{SO}_{4}$. 
FLUORAPATITE SOLUBILIZATION BY FILAMENTOUS

FUNGI ON SYNTHETIC MEDIA, NATURAL, AND

STERILE SUGAR CANE WASTE

Author: PAULO ROBSON DE SOUZA

Adviser: PROF ${ }^{a}$ DRA. ELKE JURANDY BRAN NOGUEIRA CARDOSO

SUMMARY

Six experiments were carried out in vitro in order to evaluate the effectiveness of several microorganisms in solubilizing a fluorapatite proceeding from Catalão, State of Goiás, Brazil. It was also evaluated the effects of rates of applied fluorapatite, time of cultivation, and previous partial solubilization of the fluorapatite with sulfuric acid, on the biological solubilization of the rock phosphate. The study was conducted at ambient temperature using a glucose plus nutrients solution, as well as a sterilized and non-sterilized sucar cane vinasse as culture medium.

In all experiments the culture medium was filtrated to determine the amount of solubilized phosphate 
and the $\mathrm{pH}$ of the solution. In some of the experiments the amount of reducing sugar in the filtrate and the fung 1 biomass production were also measured. Some of the fluorapatite samples were subjected to X-Ray diffraction analysis.

Six filamentous fungi were selected as the most effective phosphate solubilizers when the culture medium was glucose plus nutrients solution. Among these, two cultures of Aspergillus niger were the most effective under any of the studied culture conditions.

The highest levels of soluble phosphate were observed when the cultivation period was longer than 21 days. Aspergillus niger showed the highest solubilization rates at low levels of fluorapatite, whereas Penicillium sp was most effective at the higher levels. The composition of the culture media influenced the phosphorus solubilization by fungi, so that the correlations between $\mathrm{pH}$ and soluble phosphate varied depending on the medium used.

No changes in the mineral composition of the fluorapatite due to fungal activity was observed, although Aspergillus niger had solubilized an amount of phosphate equivalent to that found in the fluorapatite $25 \%$ solubilized by sulfuric acid. 


\section{INTRODUÇÃO}

A baixa disponibilidade de fósforo prontamente assimilável pelas plantas cultivadas nos solos brasileiros tem sido um fator limitante à produtividade agrícola do país, por ser este um elemento essencial à formação de estruturas celulares e à execução de inúmeros processos metabólícos .

As reservas de fosfato de rocha brasileiras supririam a demanda, mas os elevados teores de óxidos de alumínio e ferro neste mineral impedem sua rápida solubilização no solo, o que tem desestimulado o seu emprego direto. Assim, processos químicos e físicos têm sido utilizados, em escala industrial, para sua prévia solubilização.

Entre os processos químicos está a utilização de enxofre para produção de ácido sulfúrico, o qual age na solubilização. Por se tratar de um material importado, caro, novas alternativas tem sido buscadas, dentre as quais a utilização de microrganismos.

Por outro lado, a agroindústria brasileira tem produzido com abundância o resíduo vinhaça, o qual apresenta 
uma demanda bioquímica de oxigênio de cerca de $30 \mathrm{~g} / \mathrm{l}$, contendo, portanto, grande quantidade de matéria orgânica a ser oxidada. Quando lançado nos rios, causa acentuada diminuição na concentração de oxigênio dissolvido na água, devido à extrema elevação do metabolismo microbiano, prejudicando a flora e a fauna aquática e outros seres vivos que delas dependem.

Face a estes problemas decidiu-se estudar a solubilização de um fosfato fluorapatítico relativamente barato, com baixa capacidade de dissolução no solo, utilizando-se microrganismos como agentes solubilizadores e vinhaça como meio de cultivo. Para tanto, buscou-se estabelecer a influência da dose de fosfato, do tempo de cultivo, do tratamento prévio do fosfato com ácido sulfúrico, e a influência de meio sintético, vinhaça esterilizada e natural no comportamento de diversos microrganismos quanto à solubilização, in vitro, dessa fluorapatita. 
2. REVISÃO DE LITERATURA

\section{1. o fósforo no solo}

o fósforo na fase sólida do solo encontra-se combinado em compostos de ferro, alumínio, cálcio e na matéria orgânica, sendo de baixa solubilidade, raramente atingindo a concentração de $0,1 \mathrm{mg} / \mathrm{I}$ de $\mathrm{P}$ na solução do solo (RAIJ et al., 1983).

A adição de fosfatos solúveis em água ao solo, provoca inicialmente um grande aumento na quantidade de fósforo lábil e do fósforo em solução. O P lábil consiste principalmente de formas fracamente adsorvidas, as quais porém, com o tempo, adquirem uma constituição mineralógica mais estável e de mais difícil solubilização, o que é chamado de "fixação", reduzindo assim a eficiencia da adubação (RAIJ et a1., 1983).

A região de Cerrados, por exemplo, é considerada um dos componentes mais importantes na expansão da fronteira agrícola brasileira; nestes solos, porém, a alta fixação de fósforo (BAHIA FILHO, 1974), aliada aos valores extremamente baixos de fósforo solúvel, são umas das 
limitações mais severas à produtividade agrícola, exigindo assim a aplícação de altas doses de P (LOPES, 1983).

Uma possível solução para tal problema seria corrigílos com adubações pesadas de fosfatos naturais, com o objetivo de elevar o teor de $\mathrm{P}$ na solução do solo, pelo seu efeito lento e residual (LOMBARDI, 1981). Os resultados de tal prática são, porém, restritos, devido à baixa solubilidade dos fosfatos naturais (LOPES, 1983).

Desta forma, tais fontes de fósforo são utilizadas como matéria prima para fabricação de superfosfatos, os quais contém fósforo em forma assimilável. Nestes processos os fosfatos naturais são tratados com ácido sulfúrico, resultando superfosfato simples, e com ácido fosfórico, resultando superfosfato triplo (MALAVOLTA et alii, 1976).

Devido a todos esses problemas, e ao elevado custo da importação de enxofre para a produção de superfosfatos, durante o SIMPOSIO SOBRE FERTILIZANTES NA AGRICULTURA BRASILEIRA, em 1984, foram sugeridas medidas alternativas para a utilização de fosfatos naturais, dentre elas o estudo da solubilização biológica dessas fontes de P.

MALAVOLTA \& NEPTUNE (1983) listaram várias alternativas para maior eficiência na utilização de fosfatos em solos tropicais e subtropicais, ácidos, pobres em $\mathrm{P}$ e com alta capacidade de fixação. Dentre estas alternativas os autores levaram em consideração a utilização de fosfatos 
naturais e de seus microrganismos solubilizadores.

Outra alternativa é a acidulação parcial dos

fosfatos. Tem sido obtidos bons resultados com tal procedimento usando-se de 30 a $50 \%$ de acidulação do fosfato de rocha, pelo menos como adubo de manutenção (KANABO \& GILKES, 1987; RAJAN, 1987; RESSELER \& WERNER, 1987).

Do mesmo modo, a acidificação do solo como resultado da atividade microbiológica também pode contribuir para a solubilização de fosfatos (LOMBARDI, 1981).

\subsection{Dissolução de fosfatos por microrganismos do solo}

Os microganismos solubilizadores de fosfatos são divididos em produtores de ácidos orgânicos e produtores de ácidos inorgânicos (MERZARI, 1973).

A oxidação microbiológica da amônia e do enxofre resulta na produção de ácidos fortes como o nítrico e - sulfúrico, respectivamente, que podem contribuir para a solubilização de fosfatos pouco solúveis. Experimentos, hoje clássicos, demonstraram o efeito de Thiobacillus thiooxidans na solubilização de fosfato de rocha em solo e in vitro, via oxidação do enxofre.

SPERBER (1958 a, b) isolou vários microrganismos do solo, solubilizadores de fosfatos, representados por muitos gêneros de fungos e bactérias. Em 
cultura axênica, estudou a ação de Aspergillus niger, Penicillium sp, Nocardia sp e Escherichia freundii na solubilização de apatita, a qual fol realizada através da produção dos ácidos lático, cítrico, glicólico e succínico.

Trabalhando com vários isolados do solo, LOW \& WEBLEY (1958) atribuiram a capacidade solubilizadora às bactérias produtoras de ácído 2-ceto-glucônico, enquanto que SPERBER (1957), estudando outros microrganismos quimiorganotróficos cultivados in vitro, relacionou a secreção dos ácidos acético, propiônico, lático, glicólico, fumárico e succínico à dissolução de fosfatos de baixa solubilidade.

Avaliando a solubilização biológica de fosfatos naturais, RAMOS et alii (1968), CARVALHO et alii (1969) e EIRA \& CARVALHO (1970) mostraram ser o Aspergillus niger 0 melhor solubilizador, seguido de espécies de Penicillium, Aspergillus, Trichoderma, Fisidium e Fusarium. Também AGNIHOTRI (1970) citou Aspergillus niger como altamente eficiente na solubilização de fosfatos, devido à alta produção de ácidos orgânicos em meio de cultura.

$$
\text { SUBRAMANIAN et alii (1987) estudaram as }
$$

disponibilidades e transformações de fosfato mono e dicálcico incubados em solo por dezoito semanas. Solo tratado com Aspergillus awamori mostrou maior disponibilidade de $P$ durante todo o período de cultivo.

Também em associação com micorrizas os 
solubilizadores de fosfatos podem favorecer a produção agrícola, como foi observado por PAULINO \& AZCON (1987).

A capacidade de solubillização de fosfato natural de 24 bactérias e 2 fungos de solo rizosférico foi avaliada em meio líquido por SATTAR \& GAUR (1986). Os fungos mostraram-se mais eficientes que as bactérias. Aos sete dias de cultivo observou-se uma correlação entre solubilização de fosfato natural e acidez do meio, a qual ocorreu em todas as culturas.

Também em cultura líquida, porém enriquecida com substrato orgânico e inoculada com suspensões de solo, KUBAT et alii (1987) relataram que até $38 \%$ do fosfato de rocha Gafsa foi solubilizado em 22 semanas a $28^{\circ} \mathrm{C}$. A principal causa da dissolução foi o decréscimo do $\mathrm{pH}$ do meio.

A fim de se determinar as condições que proporcionam a maior taxa de solubilização de fosfatos insolúveis, CEREZINI et alii (1988) avaliaram o efeito de $A$. niger em cultura estacionária, utilizando-se o meio citrato modificado, suplementado com $800 \mathrm{mg}$ de fluorapatita por 1itro. A solubilização aumentou com o crescimento do fungo, atingindo 0 máximo aos 11 dias. A solubilização foi correlacionada com $0 \mathrm{pH}$ do meío, mas não com a acidez titulável, provavelmente devido à atividade metabólica do fungo, resultante do consumo de açúcar. Quando comparadas com galactose e maltose, a frutose, glicose, xilose e sacarose foram os açúcares que mais favoreceram a solubilização da 
fluorapatita. Entretanto, observaram que, apesar da frutose ter aumentado o crescimento do fungo e a acidez do meio, os níveis de fosfatos solúveis foram reduzidos, o que deve ter ocorrido devido ao consumo causado pelo rápido crescimento da biomassa fúngica.

Estes mesmos pesquisadores, avaliando o efeito de diferentes fontes de nitrogênio, observaram que os sais de amônia favoreceram a solubilização de fluorapatita mais que nitrogênio orgânico (peptona ou uréia) e nitrato, correspondendo ao $\mathrm{pH}$ mais baixo e à acidez titulável mais alta.

EIRA \& CARVALHO (1969), após estudarem a relação $C / N$ na solubilização de apatita de Araxá por microrganismos, utilizando-se glicose como substrato oxidável, relataram que relações altas $(100: 1, \quad 50: 1)$ incrementaram a solubilização. Nestas condições o fósforo solúvel permaneceu mais tempo na solução edáfica. Observaram ainda uma correlação negativa entre $\mathrm{pH}$ e fósforo solubilizado. É provável que as altas relações tenham promovido um aumento na taxa de respiração celular em relação ao crescimento, o que leva a um aumento da relação secreção de ácidos orgânicos/imobilização de fósforo nas estruturas celulares.

Os mesmos autores, em 1970, estudando o efeito dos microrganismos na variação do $\mathrm{pH}$ e solubilização de apatita de Araxá ao decompor diferentes fontes de matéria 
orgânica, notaram que tanto palha de cana quanto torta de algodão misturados ao solo elevaram $0 \mathrm{pH}$, devido à atividade microbiana. A adição de glícose ao solo, ao contrário, causou uma brusca diminuição do pH. E a adição de composto não alterou $0 \mathrm{pH}$. Em todos houve um incremento da solubilização do fosfato, indicando que outros mecanismos devem estar envolvidos no processo, além da produção de ácidos. Segundo EIRA \& CARVALHO (1970) a variação ou estabilização do pH é influenciada diretamente pela natureza do substrato orgânico em decomposição no solo.

ASSUMPÇÃo (1981), em experimento conduzido em casa-de-vegetação, concluiu que a adição de um resíduo da fermentação do melaço (ajifer) ao solo elevou a acidez, mas não se constatou a solubilização da apatita Patos de Minas. Entretanto, a incorporação de torta de algodão acarretou a alcalinização do solo e induziu a liberação de formas disponíveis de fósforo. Esta autora concluiu que, nas condições descritas, em meio líquido e sólido, a solubilização da apatita não dependeu do teor de ácido produzido por microrganismos.

LARSEN (1967) afirma que ácidos orgânicos secretados por microrganismos raramente solubilizam fosfatos, já que se decompóem rapidamente no solo. Esse autor acredita que o ácido carbônico presente na solução do solo, formado a partir do $\mathrm{CO}_{2}$ excretado pelos microrganismos, agiria na dissolução do fosfato. Contudo, sabe-se que o ácido carbônico 
é instável, não devendo permanecer por muito tempo na solução do solo.

Esse autor afirma ainda que o acúmulo de ácidos inorgânicos fortes poderia apresentar melhores resultados na dissolução desses minerais no solo.

De certa forma BAREA et alii (1970) esclarecem - fato de vários autores apresentarem resultados diversos quanto ao efeito do $\mathrm{pH}$ na solubilização, ao admitirem que não somente os ácidos orgânicos, mas enzimas extracelulares secretadas pelos microrganismos poderiam estar envolvidas no processo de solubilização: a produção de ácidos orgânicos criaria a condição ótima de pH para a atividade enzimática. Estes autores também admitem um mecanismo misto: um direto, pela solubilização enzimática, e outro indireto, pela intervenção dos ácidos.

o fato de vários autores terem obtido resultados antagônicos em relação ao efeito do $\mathrm{pH}$ na solubilização de fosfatos, pode ser justificado também baseando-se nos trabalhos de BRADDLEY \& SIELING (1953) e MICHOUSTINE (1972). Estes autores relacionaram o poder de solubilização de certos ácidos orgânicos às suas propriedades fisicoquímicas: estes podem ligar-se de modo estável a cátions como $\mathrm{Fe}, \mathrm{Al}$, $\mathrm{Mn}$ e Ca, os quais, livres, poderiam formar quelatos com o fósforo solúvel. Por este motivo dois ácidos orgânicos podem solubilizar uma quantidade desigual de fosfato, ambos produzindo o mesmo valor de $\mathrm{pH}$. 
Como exemplo de eficientes solubilizadores de fosfato citam os ácidos lático, 2-cetoglucônico, cítrico, fórmico e acético, produzidos por microrganismos.

2.3. 0 emprego de vinhaça como substrato para solubilização de fosfatos

Segundo ALMEIDA (1952), a composição química da vinhaça é bastante variável, dependendo principalmente da composição do vinho submetido à destilação, que, por sua vez, está correlacionada a outros fatores, entre os quais: natureza e composição da matéria prima, sistema usado no preparo do mosto, método de fermentação adotado e sistema de condução da fermentação alcoólica. Assim, analisando cinco amostras diferentes de vinhaça de mosto de melaço, vários autores observaram diferentes concentrações de nitrogênio (variando entre 0,57 e $1,18 \mathrm{~kg} / \mathrm{m}^{3}$ ) e de $\mathrm{P}_{2} \mathrm{O} 5$ (variando entre $\left.0,10 \mathrm{e} 0,34 \mathrm{~kg} / \mathrm{m}^{3}\right)$

Dentre os efeitos que a aplicação de vinhaça pode causar ao solo, são citados: (a) elevação do pH e aumento da disponibilidade de nutrientes pela ação direta dos componentes da matéría orgânica, e indireta, pelo aumento da atividade microbiológica e dos efeitos físicos; (b) melhoria da sua estrutura física; (c) aumento da capacidade de troca catiônica e (d) aumento da capacidade de retenção de água 
(GLORIA \& ORLANDO FILHO, 1983). De certa forma, todos esses efeitos ocorrem de modo interrelacionado. E provável que os efeitos (a) e (c) ocorram em cultivos em meio líquido.

LEAL et alii (1983), investigando as variações de $\mathrm{pH}$ e de potencial redox que acompanham a aplicação de vinhaça em um solo Podzólico Vermelho-Amarelo da região de Campos (RJ), verificaram um aumento de até 2,1 unidades de $\mathrm{pH}$ e abaixamento do potencial redox a valores menores que 300 mV. Os elevados teores de compostos orgânícos da vinhaça causaram uma explosão da população microbiana, medida pela evolução do $\mathrm{CO}_{2}$, o que ocasionou uma alta $\mathrm{DBO}$ no solo. Tendo havido uma diminuição do teor de $\mathrm{N}-\mathrm{NO}_{3}$ adicionado, é provável que o nitrato tenha sido utilizado como receptor de elétrons, devido à exaustão do oxigênio do solo. Segundo esses autores, os resultados sugeriram ainda que o conhecido aumento do $\mathrm{pH}$ do solo devido à aplìcação de vinhaça decorre de reações de redução (que consomem cátions hidrogênio), refletindo no abaixamento de potencial redox.

NEVES et alii (1983), também utilizando um solo Podzólico Vermelho-Amarelo da mesma região, observaram bruscas transformações microbiológicas decorrentes da adição de vinhaça ao solo, ocasionando a elevação do $\mathrm{pH}$ de 4,4 para 6,0 , efeito este que perdurou durante os 66 dias de experimentação. Segundo esses autores, a adição de vinhaça não somente introduziu carbono orgânico ao solo, mas também nitrogênio prontamente assimilável, o que acarretou 
inicialmente um breve aumento da população de bactérias não fixadoras de nitrogênio, inibindo temporariamente a população de fixadoras. Apesar disso, ao término do experimento foi verificado um incremento de nitrogênio total dos solos incubados com vinhaça, devido à atividade das bactérias fixadoras.

Segundo $O$ INSTITUTO NACIONAL DE TECNOLOGIA (1978), bactérias podem inibir o crescimento de fungos filamentosos que oxidam a vinhaça, digerindo componentes da parede celular através de uma intima relação parasítica. 0 uso de bentonita, uma argila adsorvente, melhorou $\circ$ rendimento dos ensaios, embora não se tenha conseguido o desenvolvimento normal de Aspergillus orizae.

Neste trabalho, incubando-se $A$. orizae por 40 dias em 1000 litros de vinhaça tratada com bentonita, houve uma redução de $69 \%$ da DBO. Contudo, devido à citada sensibilidade deste fungo a contaminantes, o pré-tratamento da vinhaça com a argila a níveis mais eficientes tornaria o processo anti-econômico, havendo a possibilidade de não apresentar bons resultados quanto à redução da DBO.

Outro trabalho parece indicar que a fermentação da vinhaça não consegue eliminar o seu poder poluente: VENTURINI FILHO (1986), estudando a produção de biomassa in vitro por $A$. oryzae utilizando vinhaça, obteve uma taxa de redução de $\mathrm{DBO} 5$ de até $84,4 \%$ após a fermentação; contudo, a vinhaça apresentou ainda elevada carga poluente 
$(\mathrm{DBO} 5=2.240,7 \mathrm{mg}$ de $\mathrm{O} 2 / 1)$

Quanto à solubilização de fosfatos in vitro tendo vinhaça como substrato oxidável, ISHISAKI (1987), referindo-se à solubilização de apatita de Araxá por A. niger em agitação circular, relatou que tanto em vinhaça esterilizada quanto em não esterilizada, à temperatura ambiente, houve um rendimento de aproximadamente 78 e $79 \%$, respectivamente, após 15 dias de cultivo. Resultados semelhantes foram observados em cultura estacionária à temperatura de $30^{\circ} \mathrm{C}$. Porém, no ensaio com agitação horizontal na forma oscilante, foram obtidos teores de fosfato solubilizado bem abaixo dos observados nos outros ensaios. 
3. METODOLOGIA

\subsection{Local de conduao dos experimentos}

Os seis experimentos foram conduzidos no Laboratório de Microbiologia do Solo, Departamento de Solos, Geologia e fertilizantes da ESALQ, no período de maio de 1988 a junho de 1989.

\subsection{Fosfato de rocha utilizado}

O fosfato de rocha utilizado, comercializado como "Fosfino", foi classificado por BITTENCOURT ${ }^{2}$ como sendo de origem ígnea, com teores de óxidos de ferro e aluminio acima de $8 \%$ E considerado um fosfato de baixa reatividade. Procede de Catalão, Goiás. E produzido pela COPEBRÁS através da flotação do mineral moído, constituindo-se no resíduo retido no ultrafiltro. Apresenta $1,84 \%$ de $\mathrm{P} 2 \mathrm{O} 5$ solúvel em

1. BITTENCOURT, V. C. de. (ESALQ,Departamento de Química) Comunicação pessoal, 1988. 
solução aquosa de citrato de amônio, e 30,73\% de P2Os total, segundo análises do Departamento de Solos, Geologia e Fertilizantes da ESALQ. A análise cristalográfica definiu-o como sendo uma fluorapatita - $\mathrm{Ca5F}\left(\mathrm{PO}_{4}\right)_{3}$.

\subsection{Microrganismos utilizados e isolamento}

Parte dos microrganismos testados foi obtida da coleção de culturas do Laboratórío de Microbiologia do Solo do LSG-ESALQ. Os outros microrganismos foram isolados de três solos diferentes: Areia Quartzosa, Série Ribeirão Claro (cultivado com gramineas nativas); Terra Roxa Estruturada, Série Luiz de Queiroz (com cultivo de grama Batatais) e solo de aluvião, do Rio Piracicamirim. Utilizou-se o método de FOSTER \& DAVIS (1949) para isolamento de microrganismos produtores de ácidos orgânicos em meio sólido contendo o indicador de $\mathrm{pH}$ verde de bromocresol. Ao contrário do recomendado pelo método, preferiu-se ajustar $0 \mathrm{pH}$ antes da esterilização, para se evitar possíveis contaminações.

Uma vez feito o plaqueamento por diluição em série, o material foi incubado a $30^{\circ} \mathrm{C}$ por 4 dias.

As colônias produtoras de ácidos foram identificadas por formarem um halo amarelo à sua volta, contrastando com a cor verde-azulada do meio. Estas colônias foram transferidas para meio idêntico, visando a obtenção de 
culturas axênicas.

Uma vez obtidas sessenta culturas, estas foram identificadas numericamente e por origem, e cultivadas em meio BDA inclinado, para posterior conservação.

\subsection{Manutenção de cultura axênica}

Sabendo-se que subcultivos prolongados podem causar a perda irreversível da capacidade solubilizadora de muitos microrganismos (PAUL \& SUNDARA-RAO, 1971), os fungos foram preservados adaptando-se o método de Castellani ${ }^{2}$, citado por FIGUEIREDO (1967) e FIGUEIREDO \& PIMENTEL (1975), os quais, empregando-o, obtiveram excelentes resultados ${ }^{3}$. 0 método consiste em manter, em condições asséticas, fragmentos de meio sólido, totalmente colonizados, em tubos contendo água destilada. Os tubos devem ser fechados hermeticamente e guardados em local escuro.

2. CASTELlANI, A. Viability of some pathogenic fungi in Distilled Water. J. Trop. Med \& Hyg., 24:270-276, 1939.

3. Estes autores conseguiram conservar as características morfofisiológicas de fungos fitopatogênicos por mais de 10 anos, sem necessidade de repique. 


\title{
3.5. Preparo do inóculo
}

\begin{abstract}
Propágulos mantidos em tubo com água destilada foram transferidos para outro tubo com meio BDA inclinado e cultivados por uma semana em estufa, a $30^{\circ} \mathrm{C}$.

Findo este periodo, ao tubo de cultivo foram adicionados $4 \mathrm{ml}$ de solução de Tween $0,1 \%$ estéril, para posterior agitação em Vortex.

Em todos os experimentos utilizou-se uma alíquota de $0,1 \mathrm{ml}$ desta suspensão de esporos e hifas para cada $50 \mathrm{ml}$ de meio de cultura. No controle experimental o inóculo foi substituído por igual volume de água destilada estéril.
\end{abstract}

3.6. Condições de cultivo

Utilizaram-se $50 \mathrm{ml}$ de meio líquido em frascos Erlenmeyer de $250 \mathrm{ml}$, mantidos à temperatura ambiente em agitador horizontal não circular.

o meio de cultivo foi esterilizado em autoclave a uma atm por 20 minutos. 


\subsection{Filtração}

Concluído o cultivo, o conteúdo do Erlenmeyer foi filtrado em papel Inlab tipo 10; o filtrado, isento de células e fosfato não-solubilizado, foi então utilizado para a determinação dos valores de $\mathrm{pH}$, fosfato solubilizado e açúcares redutores, conforme o experimento. Quando da não-utilização imediata deste material, o mesmo era conservado à temperatura de $4^{\circ} \mathrm{C}$.

\subsection{Determinação do fósforo solubilizado}

Colocou-se em tubos de ensaio un mililitro do meio de cultura filtrado. Em seguida foram adicionados $10 \mathrm{ml}$ do reagente vanado-molíbdico descrito por SARRUGE \& HAAG (1974). Após agitação e 10 minutos em repouso foi feita a leitura em colorímetro fotoelétrico (comprimento de onda = $420 \mathrm{~nm}$ ).

Para o preparo dos padrões de fósforo foi utilizada uma solução de $\mathrm{KH}_{2} \mathrm{PO}_{4} 1,9173 \mathrm{~g} / 1$. Desta solução foram retirados $1,3,5,10,20,30,40$ e $46 \mathrm{ml}$, os quais foram postos em balão volumétrico contendo $4 \mathrm{ml}$ de $\mathrm{H}_{2} \mathrm{SO}_{4}$ 10N, completando-se o volume a $50 \mathrm{ml}$ com água destilada.

A reta-padrão foi construida utilizando-se uma alíquota de $1 \mathrm{ml}$ destas diluições, somada a $10 \mathrm{ml}$ da solução 
vanado-molíbdica. Obteve-se uma regressão linear com $r$ igual a 0,997. Quando a leitura de uma alíquota do filtrado apresentava valores de transmitância menores que $20 \%$, o material era diluído em água destilada na proporção 1:9, multiplicando-se posteriormente por 10 a concentração calculada.

3.9. Determinação do nitrogênio, resíduo orgânico, carbono orgânico e resíduo mineral total

Estas determinações foram efetuadas pelo Departamento de Solos, Geologia e Fertilizantes da ESALQ, segundo métodos clássicos, descritos por KIEHL \& PORTA (1980).

3. 10. Leitura dos valores de $\mathrm{pH}$

Foi feita utilizando-se um potenciômetro digital, padrões 4,01 e 6,86 , até 3 horas depois da coleta do filtrado. 


\subsection{Determinação da biomassa microbiana}

Para a quantificação da biomassa utilizou-se papel de filtro desidratado por uma semana em estufa a $60^{\circ} \mathrm{C}$ e tarado. Após a filtração, este filtro contendo ou não fosfato de rocha e micélio era, então, posto a secar nas mesmas condições, até massa constante, sendo a quantidade de biomassa determinada pela diferença entre a massa inicial e final do filtro, descontando-se desta a massa do fosfato aplicado.

\subsection{Análise estatística}

Fez-se a análise da variância utilizando-se o teste F. Utilizou-se o teste de Tukey para comparação de médias ao nível de $5 \%$ de probabilidade e análises de regressão, quando necessárỉo.

3.13. Seleção de microrganismos solubilizadores de fosfato - EXPERIMENTO 1

o objetivo deste experimento foi selecionar cinco culturas com maior capacidade de solubilização de fluorapatita in vitro, a partir de 45 culturas axênicas de 
fungos filamentosos e 5 de culturas axênicas de bactérias do solo, obtidas conforme descrito no item 3.3 .

Como meio de cultivo utilizou-se a solução de HOAGLAND \& ARNON (1950), modificada conforme a seguir:

$\begin{array}{lr}\mathrm{KNO}_{3} \text { 1M } & 5 \mathrm{ml} \\ \mathrm{Ca}\left(\mathrm{NO}_{3}\right)_{2} 1 \mathrm{M} & 5 \mathrm{ml} \\ \mathrm{MgSO}_{4} .7 \mathrm{H} 2 \mathrm{O} 1 \mathrm{M} & 2 \mathrm{ml} \\ \text { Sol. micronutrientes } & 1 \mathrm{ml} \\ \text { FeEDTA } & 1 \mathrm{ml} \\ \text { Água destilada } & 1000 \mathrm{ml} \\ \text { Glicose } & 50 \mathrm{~g}\end{array}$

(Solução de mícronutrientes: $2,86 \mathrm{~g} \mathrm{H} \mathrm{HBO}_{3} ; 1,81 \mathrm{~g}$ $\mathrm{MnCl} 2.4 \mathrm{HzO} ; 0,1$ g $\mathrm{ZnCl} 2 ; 0,04 \quad \mathrm{~g} \quad \mathrm{CuCl}_{2} ; 0,02$ gramas de $\mathrm{H}_{2 \mathrm{MoO}}$. $\mathrm{H} 2 \mathrm{O}$. Completou-se a 1 litro com água destilada.)

o meio foi esterilizado em autoclave nas condições descritas no item 3.6. A dose de fosfato empregada foi de $1,0 \mathrm{~g}$ de fluorapatita natural por $50 \mathrm{ml}$ do meio.

Após 7 dias analisaram-se as variáveis teor de fosfato solubilizado, valor do $\mathrm{pH}$ e biomassa microbiana.

0 delineamento experimental, inteiramente ao acaso, envolveu 50 culturas mais o controle, com três repetições por tratamento, totalizando 153 parcelas. 
3.14. Efeito de fungos e do $\mathrm{H}_{2} \mathrm{SO}_{4}$ na composição mineralógica e na solubilização da fluorapatita EXPERIMENTO 2

Foram utilizadas as culturas $09,25,34,60 \mathrm{e}$ 28, escolhidas entre as que mais solubilizaram fluorapatita no EXPERIMENTO 1. As culturas 09, 34 e 60 foram identificadas como sendo Aspergillus niger, enquanto a cultura 25, como Penicillium sp. Estas foram cultivadas por 7 dias, em maio de 1988, utilizando-se o meio empregado no EXPERIMENTO 1 , em condições asséticas.

Como fonte de fósforo foi utilizada, na dose $1,0 \mathrm{~g} / 50 \mathrm{ml}$ de meio, fluorapatita em estado natural e parcialmente solubilizada por ácido sulfúrico concentrado, a saber:

a) Fluorapatita $25 \%$ solubilizada

(33g $\mathrm{H}_{2} \mathrm{SO}_{4} / 2 \mathrm{OOg}$ rocha)

b) Fluorapatita $50 \%$ solubilizada

(66g H2SO $4 / 200 \mathrm{~g}$ rocha)

c) Fluorapatita $75 \%$ solubilizada

(99g $\mathrm{H}_{2} \mathrm{SO}_{4} / 2 \mathrm{OOg}$ rocha)

d) Fluorapatita $100 \%$ solubilizada

(126g H2SO $4 / 200$ g rocha),

cuja análise química encontra-se na Tabela 1. 
o experimento, do tipo fatorial, fol conduzido em delineamento inteiramente casualizado, sendo o fator $A$, os cinco fungos e um controle, e fator B, fluorapatita bruta e tratada com as quatro diferentes quantidades de ácido. Foram utilizadas 3 repetições, totalizando 90 parcelas.

Tabela 1 - Análise dos teores de $\mathrm{P}_{20} \mathrm{e}$ e valores de $\mathrm{pH}$ dos fosfatos natural e parcialmente solubilizados em $\mathrm{H}_{2} \mathrm{SO}_{4}$.

\begin{tabular}{cccc}
\hline $\begin{array}{c}\text { FLUORAPATITA } \\
(\% \text { SOLUBILIZAÇÃO) }\end{array}$ & $\begin{array}{c}\text { P2O5 SOL. AQUOSA } \\
+ \text { CITRATO DE } \\
\text { AMONIO }(\%)\end{array}$ & $\begin{array}{c}\text { P2O5 } \\
\text { TOTAL } \\
(\%)\end{array}$ & pH \\
\hline O0 (Natural) & 1,84 & 30,73 & 5,2 \\
25 & 7,16 & 26,88 & 3,3 \\
50 & 13,47 & 22,87 & 3,0 \\
75 & 17,05 & 19,67 & 2,8 \\
100 & 18,91 & 19,00 & 2,6 \\
\hline
\end{tabular}

Foram determinados no filtrado os teores de fósforo solubilizado e os valores de $\mathrm{pH}$.

Foi feita uma análise cristalográfica da fluorapatita natural e acidificada, e ainda determinados os teores de açúcares redutores, no filtrado, conforme descrição metodológica a seguir. 


\section{Análise cristalográfica}

Esta análise foi efetuada no Departamento de Solos, Geologia e Fertilizantes da ESALQ, pelo método da difração de Raio-X.

Foram analisadas as cinco amostras de fluorapatita não submetidas à atividade fúngica, sendo uma amostra natural e quatro aciduladas, e também uma amostra de fluorapatita natural submetida à atividade de $A$. niger, cultura 34, a qual solubilizou os maiores teores de fósforo no EXPERIMENTO 1. A amostra submetida à atividade fúngica resultou da filtragem, dessecação e trituração do material sólido contido em vinte frascos mantidos sob as condições ambientais estabelecidas para este experimento.

Especificações técnìcas:

Radiação $\mathrm{K} \propto \mathrm{Cu} \lambda=1,54 \AA$

Limite de contagem: 400 cps

Varredura: $18-50^{\circ} 2 \theta$

Constante de tempo: 15

Velocidade do goniômetro: $1^{\circ}$. 20/min.

Alta tensão: $40 \mathrm{hv}$ 20ma

A distância $\alpha$ com interferência positiva pela condição de Bragg, identificada pelos picos de intensidade dos difratogramas, é dada pela fórmula 


$$
\alpha=2 \lambda / \operatorname{sen} \theta
$$

a qual identifica os produtos cristalinos formados.

\section{Determinação de açúcares redutores}

Feita no Laboratório de Bioquímica do Centro de Energia Nuclear na Agricultura - USP, pelo método descrito por SOMOGYI (1952).

o filtrado foi diluído inicialmente em água destilada na proporção 1:50. Devido às características físicas deste material, a fase de extração, recomendada pelo método, não foi executada.

As determinações foram feitas tomando-se por base una reta-padrão obtida a partir de uma solução de glicose $200 \mu \mathrm{g} / \mathrm{ml}$, com 7 pontos de leitura $(\gamma=235,9339-$ $0,6194 ; r=0,9998)$.

Fez-se a leitura em espectrofotometro, a $530 \mathrm{~nm}$, en duplicatas, utilizando-se diluições cujas leituras se ajustaram à reta. 
3.15. Efeito de dose de fosfato, fungo e tempo de cultivo na solubilização da fluorapatita bruta EXPERIMENTO 3.

Com este experimento, instalado em agosto de 1988, determinou-se a dose e o período de cultivo ideais para a solubilização do fosfino, visando a instalação dos experimentos 4,5 e 6 .

Para melhor compreender o processo, e por questões práticas, decidiu-se pela utilização de apenas duas culturas fúngicas: Penicillium sp (cultura 25), considerada como a pior solubilizadora dentre as selecionadas no EXPERIMENTO 1 , tendo apresentado o $\mathrm{pH}$ mais elevado deste grupo; A. niger (cultura 34), por ter apresentado o maior teor de fósforo solubilizado naquele experimento e os menores valores de $\mathrm{pH}$.

Os fungos foram incubados por $2,7,14$ e 21 dias.

o meio de cultura empregado foi o mesmo descrito para o experimento 1, esterilizado, utilizando-se as doses: $0,5,1,0,2,0$ e $3,0 \mathrm{~g}$ de fluorapatita bruta por $50 \mathrm{ml}$ de meio.

Foram analisadas as variáveis concentração de fósforo solúvel no filtrado, valores de $\mathrm{pH}$ e biomassa.

0 experimento, do tipo fatorial ( 4 doses de fosfato $\times 3$ fungos e controle x 4 épocas), foi instalado 
de forma inteiramente casualizada, com três repetições, totalizando 144 parcelas.

3.16. Solubilização biológica do fosfato, aplicado em doses crescentes, em diferentes períodos de cultivo, utilizando-se vinhaça esterilizada EXPERIMENTO 4

Este experimento foi instalado em outubro de 1988, utilizando-se duas das culturas fúngicas que apresentaram melhor solubilização do fosfino bruto e maior acidificação do meio no EXPERIMENTO $2(34,60-A$. niger $)$, e a cultura 25 (Penicillium sp.), que nesse experimento causou baixa solubilização e não alterou significativamente $\circ \mathrm{pH}$ do meio.

Decidiu-se ampliar o periodo de cultivo para 12, 20 e 42 dias, devido aos resultados obtidos no EXPERIMENTO 3.

Foi utilizada, como meio de cultivo, vinhaça proveniente da fermentação de mosto de cana, coletada na tubulação de saída da Usina Costa Pinto, município de Piracicaba, no mês de setembro de 1988. As propriedades dessa vinhaça são as seguintes: 
29.

$\begin{array}{lc}\text { Indice pH } & 4,09 \\ \text { Umidade total (natural) a 110. C } & 10,03 \mathrm{~g} / 1 \\ \text { Mat. orgânica total (combustão) } & 7,37 \mathrm{~g} / 1 \\ \text { Resíduo mineral total } & 2,66 \mathrm{~g} / 1 \\ \text { Resíduo mineral insolúvel } & 0,12 \mathrm{~g} / 1 \\ \text { Resíduo solúvel } & 2,53 \mathrm{~g} / 1 \\ \text { Nitrogênio total } & 0,12 \mathrm{~g} / 1 \\ \text { Fósforo (P205) total } & 0,06 \mathrm{~g} / 1 \\ \text { Potássio (K20) total } & 0,91 \mathrm{~g} / 1\end{array}$

Para a conservação da vinhaça aproximadamente $2.000 \mathrm{ml}$ deste material foram acondicionados em frascos cúbicos de polietileno e mantidos à temperatura de $20^{\circ} \mathrm{C}$, sendo postos a descongelar à temperatura ambiente 12 horas antes da utilização.

Foram empregados $0,5,1,0$ e $3,0 \mathrm{~g}$ de fluorapatita por $50 \mathrm{ml}$ de meio.

Analisou-se o teor de fosfato solubilizado e determinou-se $\mathrm{o} \mathrm{pH}$.

0 experimento foi do tipo fatorial ( 3 épocas $x$ 4 fungos e controle $x \quad 3$ doses de $\mathrm{P}$ ), conduzido em delineamento inteiramente casualizado, com três repetições, totalizando 108 parcelas. 
3.17. Mineralização do fósforo orgânico e solubilização do fosfato bruto em vinhaça natural, em ausência e presença de fungos selecionados - EXPERIMENTO 5

o objetivo deste experimento, instalado na mesma data do experimento 4, foi: (a) medir a possivel interferência do fósforo solúvel da própria vinhaça nos resultados; (b) medir o efeito de substâncias e/ou microrganismos presentes na vinhaça na solubilização da fluorapatita; e (c) conhecer o comportamento, em vinhaça natural, de três fungos com diferentes capacidades de solubilização de fosfato, de acordo com os ensaios anteriores: elevada (A. niger cultura 60), média (A. niger cultura 34) e baixa (Penicillium sp - cultura 25). Para atingir o objetivo (a) utilizou-se apenas a cultura 34 .

Optou-se por um delineamento inteiramente casualizado, com seis tratamentos com repetições diversas, a saber:

1. sem fosfato e com fungo 34 - 5 repetições;

2. sem fosfato e sem fungo - 3 repetições;

3. com fosfato e sem fungo - 5 repetições;

4. com fosfato e fungo 60 - 5 repetições;

5. com fosfato e fungo $25 \quad-4$ repetições;

6. com fosfato e fungo $34 \quad-5$ repetições.

Total de parcelas: 27 
Utilizou-se como melo, vinhaça não esterilizada (proveniente do mesmo lote empregado no experimento 4) e $1,0 \mathrm{~g}$ de fluorapatita por $50 \mathrm{ml}$ de meio, quando exigida.

Após 42 dias de cultivo foram avaliados o teor de fosfato solúvel e os valores de $\mathrm{pH}$.

A análise estatística foi felta de acordo com o descrito no item 3.12 , mas com ajustes para experimento desbalanceado.

3.18. Solubilização de fosfino bruto utilizando-se fungos selecionados, vinhaça natural e esterilizada - EXPERIMENTO 6

o objetivo do experimento foi avaliar o efeito da introdução de fungos selecionados na solubilização de fosfino em vinhaça natural e esterilizada.

0 delineamento experimental foi inteiramente casualizado, constituido de oito tratamentos com repetições diversas, a saber: 
1. vinhaça natural sem fungo

2. vinhaça natural com fungo 34

3. vinhaça natural com fungo 25

4. vinhaça natural com fungo 60

5. vinhaça esterilizada sem fungo

6. vinhaça esterilizada com fungo $34-3$ repetições;

7. vinhaça esterilizada com fungo $25-3$ repetições;

8. vinhaça esterilizada com fungo 60 - 3 repetições;

- 5 repetições;

-5 repetições;

- 5 repetições;

-5 repetições;

- 3 repetições;

Total de parcelas: 32

o material fol cultivado por 42 dias, utilizando-se $1,0 \mathrm{~g}$ de fluorapatita bruta por $50 \mathrm{ml}$ de meio. Foram avaliados o teor de fósforo solúvel e os valores de $\mathrm{pH}$.

A análise estatística foi feita de acordo com - item 3.12, com ajustes para experimento desbalanceado. 
4.1 Seleção de microrganismos solubilizadores de fosfato - EXPERIMENTO 1

Na Tabela 2 percebe-se que houve diferenças significativas nas variáveis fósforo solubilizado $\mathrm{pH}$ e biomassa, e todas apresentaram coeficiente de variação aceitável.

Tabela 2 - Análise da variância para fósforo solubilizado,pH e biomassa das culturas de microrganismos.

\begin{tabular}{|c|c|c|c|c|}
\hline \multirow{2}{*}{$\begin{array}{l}\text { CAUSAS DA } \\
\text { VARIAÇÃO }\end{array}$} & \multirow{2}{*}{$\begin{array}{l}\text { GRAUS DE } \\
\text { LIBERDADE }\end{array}$} & \multicolumn{3}{|c|}{ QUADRADO MEDIO } \\
\hline & & FÓSFORO & $\mathrm{pH}$ & BIOMASSA \\
\hline Tratamento & 50 & $74,58^{* *}$ & $3,69^{* *}$ & $0,06^{* *}$ \\
\hline Resíduo & 102 & 1,46 & 0,04 & 0,01 \\
\hline Total & 152 & & & \\
\hline
\end{tabular}


Com relação ao fósforo solubilizado, nota-se na Tabela 3 que das 50 culturas testadas, 24 superaram 0 controle ao nível de $5 \%$ de probabilidade, pelo teste de Tukey, destacando-se os fungos 25 (Penicillium sp), 34, 09, 18 e 60 (identificado como sendo Aspergillus niger); e 27 e 28, que solubilizaram de 16,9 a $13,6 \mathrm{mg} P / 1$ em uma semana. Nenhuma das culturas bacterianas diferiu do controle.

Na Tabela 3 observa-se que 0 pH variou entre os limites 6,5 e 2,8. A exceção do fungo 25 (Penicillium sp), que apresentou 0 valor de $\mathrm{pH}$ 4,3, não diferindo significativamente do controle $(4,7)$, os demais fungos apontados como os melhores solubilizadores apresentaram os mais baixos valores de $\mathrm{pH}$, variando de 2,8 a 3,0 . Algumas culturas, apesar de acidificarem o meio a valores de $\mathrm{pH}$ inferiores a 4,0, diferindo significativamente do controle, não solubilizaram o fosfato. As culturas bacterianas foram responsáveis pelo mais elevados valores de $\mathrm{pH}$.

Houve correlação negativa e significativa (0,6203 ) entre pH e fósforo solubilizado.

Quanto à biomassa microbiana (Tabela 3), pelo teste de Tukey observou-se que os seis fungos que mais solubilizaram o fosfato não diferiram estatisticamente do controle: para estes foram observados valores entre 0,7248 e $0,6677 \mathrm{~g}$ (controle $=0,5201 \mathrm{~g}$. ). 
Dadas as características granulométricas do fosfato empregado, o método de quantificação da biomassa apresentou limitações: não se conseguiu, por métodos físicos, separar o componente fúngico do fosfato bruto, intimamente agregados. Tentou-se digerir o micélio com peróxido de hidrogênio concentrado e ácidos fortes e, mesmo sob a condição $120^{\circ} \mathrm{C} 1$ atm, não se obteve sucesso. Desta forma, o valor do controle era dado pela pesagem do filtro contendo a dose de fosfato empregado. Nos tratamentos com fungo, eventuais substituições da massa de fosfato solubilizado, perdida na filtragem, por biomassa com peso equivalente, não foram notadas. Contudo, uma acurada observação dos fungos em crescimento e do material retido no filtro permitiu a aceitação destes resultados como válidos.

4.2. Efeito de fungos e do $\mathrm{H}_{2} \mathrm{SO}_{4}$ na composição mineralógica e na solubilização da fluorapatita EXPERIMENTO 2

\footnotetext{
Houve efeito dos tratamentos sobre as quantidades de fósforo solubilizado, açúcares redutores e os valores de $\mathrm{pH}$; houve interação entre os fatores fungo e fosfato (Tabela 4).
} 
TABELA 3 - Teste de Tukey para as médias dos tratamentos, variáveis: fósforo solubilizado, $\mathrm{pH}$ e biomassa ( $\mathrm{n}$ ㅇ repetições $=3$ )

\begin{tabular}{|c|c|c|c|c|c|c|c|c|c|}
\hline \multirow{4}{*}{$\frac{N Q}{O R D E M}$} & \multirow{4}{*}{$\frac{N \mathscr{N O}}{18}$} & \multirow{2}{*}{\multicolumn{2}{|c|}{$D_{D A}^{\text {IDENTIFICACÃO }}$ CULTURA }} & \multicolumn{6}{|c|}{$M E ́ D I A S$} \\
\hline & & & & \multicolumn{2}{|c|}{$\begin{array}{c}F O S F O R O \\
\text { SOLUBILIZADO } \\
(\mathrm{mg} / \mathrm{l})\end{array}$} & \multicolumn{2}{|c|}{$p H$} & \multicolumn{2}{|c|}{ BIOMASSA $(g)$} \\
\hline & & 25 & Penicillium sp & 16,9 & $a$ & 4,9 & $d$ & 0,7176 & $b c$ \\
\hline & & 34 & Aspergillus niger & 16,8 & $a$ & 3,0 & $f$ & 0,6677 & $b c$ \\
\hline 9 & 6 & 9 & A. niger & 16,5 & $a$ & 2,9 & $f$ & 0,7240 & $b c$ \\
\hline 4 & 21 & 28 & - & 15,2 & $a b$ & 3,0 & $f$ & 0,6871 & $b c$ \\
\hline 5 & 13 & 18 & A. niger & 14,9 & $a b c$ & 3,0 & $f$ & 0,7248 & $b c$ \\
\hline 6 & 49 & 60 & A. niger & 13,6 & $a b c d$ & 3,0 & $f$ & 0,7239 & $b c$ \\
\hline 7 & 20 & 27 & - & 13,5 & $a b c d$ & 3,0 & & 0,7054 & $b c$ \\
\hline 8 & 90 & 39 & - & 12,2 & $b c d$ & 2,8 & $f$ & 0,5883 & $b c$ \\
\hline$g$ & 29 & 38 & - & 11,9 & $b c d$ & 3,8 & $e$ & 1,1404 & $a$ \\
\hline 10 & 39 & 44 & - & 11,5 & $b c d$ & 2,9 & $f$ & 0,6449 & $b c$ \\
\hline 11 & 38 & 52 & - & 10,9 & $c d$ & 2,9 & $f$ & 0,7643 & $a b$ \\
\hline 12 & 40 & 55 & - & 10,0 & de & 2,9 & $f$ & 0,6709 & $b c$ \\
\hline 13 & 28 & 36 & - & 8,9 & $\boldsymbol{e}$ & 3,1 & $f$ & 0,6877 & $b c$ \\
\hline 14 & 19 & 26 & - & 8,5 & $e$ & 3,0 & $f$ & 0,9111 & $a b$ \\
\hline 15 & 17 & 22 & A. niger & 8,1 & $e$ & 3,1 & $f$ & 0,7104 & $b c$ \\
\hline 16 & 14 & 19 & Aspergilus awamori & 7,4 & $e$ & 9,4 & ef & 0,7434 & $b c$ \\
\hline 17 & 31 & 40 & - & 6,7 & $e$ & 3,3 & $f$ & 0,7786 & $a b$ \\
\hline 18 & 24 & 92 & - & 6,6 & $e$ & 3,0 & $f$ & 0,6196 & $b c$ \\
\hline 19 & 34 & 45 & - & 6,2 & ef & 3,2 & $f$ & 0,5695 & $b c$ \\
\hline 20 & 23 & 91 & - & 6,2 & ef & 9,1 & $f$ & 0,6963 & $b c$ \\
\hline 21 & 51 & 49 & $\ldots$ & 5,6 & $f$ & 3,4 & $f$ & 0,6342 & $b c$ \\
\hline 22 & 48 & $19 B$ & Bactéria & 5,5 & $f$ & 3,1 & $f$ & 0,3529 & $c$ \\
\hline 23 & 46 & $7 B$ & Bactéria & 5,4 & $f$ & 3,1 & $f$ & 0,4864 & $c$ \\
\hline 24 & 49 & $17 B$ & Bactéria & 5,2 & $f$ & 9,5 & $e$ & 0,4012 & $c$ \\
\hline 25 & 44 & 61 & - & 4,8 & $f g$ & 5,6 & $e$ & 0,6528 & $b c$ \\
\hline 26 & 16 & 21 & Polyporus & 4,5 & $f g$ & 4,0 & $d e$ & 0,4919 & $c$ \\
\hline 27 & 42 & 58 & - & 9,6 & $f g$ & 3,1 & $f$ & 0,7160 & $b c$ \\
\hline 28 & 45 & $6 B$ & Bactéria & 9,5 & $f g$ & 4,3 & $d$ & 0,5490 & $b c$ \\
\hline 29 & 5 & 8 & - & 3,1 & $f g$ & 3,3 & $f$ & 0,6626 & $b c$ \\
\hline 30 & 22 & 30 & - & 9,0 & $f g$ & 3,4 & $e$ & 0,7983 & $a b$ \\
\hline 91 & 25 & 93 & - & 2,9 & $f g$ & 3,4 & $f$ & 0,7769 & $a b$ \\
\hline 32 & 10 & 15 & - & 2,8 & $f g$ & 4,7 & $c$ & 0,4881 & $c$ \\
\hline 93 & 27 & 35 & - & 2,4 & $f g$ & 9,3 & $f$ & 0,7140 & $b c$ \\
\hline 34 & 4 & 5 & - & 1,8 & $g$ & 6,4 & $a b$ & 0,5035 & $c$ \\
\hline 35 & $i$ & 1 & - & 1,7 & $g$ & 6,4 & $a b$ & 0,5593 & $b c$ \\
\hline 96 & 37 & 51 & - & 1,6 & $g$ & 6,5 & $a$ & 0,4505 & $c$ \\
\hline 97 & 2 & 2 & - & 1,5 & $g$ & 5,1 & $c$ & 0,5926 & $b c$ \\
\hline 38 & 8 & 19 & - & 1,5 & $g$ & 4,1 & $d$ & 0,5892 & $b c$ \\
\hline 39 & 36 & 49 & - & 1,5 & $g$ & 4,6 & $d$ & 0,6257 & $b c$ \\
\hline 40 & 92 & 41 & - & 1,4 & $g$ & 4,3 & $d$ & 0,5619 & $b c$ \\
\hline 41 & 3 & 4 & - & 1,4 & $g$ & 4,4 & $d$ & 0,5540 & $b c$ \\
\hline 42 & 7 & 11 & - & 1,4 & $g$ & 4,5 & $d$ & 0,5426 & $b c$ \\
\hline 43 & 35 & 47 & - & 1,4 & $g$ & 3,9 & $e$ & 0,6687 & $b c$ \\
\hline 44 & 12 & 17 & - & 1,9 & $g$ & 5,1 & $c$ & 0,5662 & $b c$ \\
\hline 45 & 41 & 56 & - & 1,2 & $g$ & 4,6 & $c d$ & 0,5685 & $b c$ \\
\hline 46 & 11 & 16 & - & 1,0 & $g$ & 5,9 & $a b$ & 0,4748 & $c$ \\
\hline 47 & 50 & 62 & (controle) & 0,9 & $g$ & 4,7 & $c$ & 0,5201 & $b c$ \\
\hline 48 & 39 & 54 & - & 0,9 & $g$ & 5,2 & c & 0,5839 & $b c$ \\
\hline 49 & 47 & $12 B$ & Bactéria & 0,8 & $g$ & 5,1 & $c$ & 0,4130 & $c$ \\
\hline 50 & 15 & 20 & Trichoderma lignorum & 0,8 & $g$ & 6,4 & $a b$ & 0,4707 & $c$ \\
\hline 51 & 9 & 14 & - & 0,7 & $g$ & 6,2 & $a b$ & 0,4355 & $c$ \\
\hline$D M S=$ & & & & 4,0 & $(5 \%)$ & 0,6 & $(5 \%)$ & 0,4 & $(1 \%)$ \\
\hline
\end{tabular}

Médias seguidas por letras distintas diferem entre si ao nível de $5 \%$ de significância. Os tratamentos foram ordenados de acordo com o teor de fósforo solubilizado. 
Tabela 4 - Análise da variância para fósforo solubilizado, pH e açúcares redutores.

\begin{tabular}{|c|c|c|c|c|}
\hline \multirow{2}{*}{ C. V. } & \multirow{2}{*}{ G.L. } & \multicolumn{3}{|c|}{ Q.M. } \\
\hline & & FÓSFORO & $\mathrm{pH}$ & AÇUCARES \\
\hline Fungo & 5 & $171,35^{* *}$ & $2,90^{* *}$ & $898,25^{* *}$ \\
\hline Fosfato & 4 & $2581,95^{* *}$ & $2,83^{* *}$ & $1510,42^{* *}$ \\
\hline $\begin{array}{l}\text { Fungo } x \\
\text { Fosfato }\end{array}$ & 20 & $14,18^{* *}$ & $0,34^{* *}$ & $244,74^{* *}$ \\
\hline Resíduo & 60 & 6,00 & 0,04 & 57,62 \\
\hline Total & 89 & & & \\
\hline $\begin{array}{l}C \cdot V \cdot= \\
(* *)=s\end{array}$ & & $\begin{array}{c}8,6 \% \\
\text { vo ao níve }\end{array}$ & $\begin{array}{l}7,6 \% \\
6 . \text { de }\end{array}$ & $\begin{array}{c}16,0 \% \\
\text { abilidade. }\end{array}$ \\
\hline
\end{tabular}

Os fungos 09 e 60 (A. niger) foram os melhores solubilizadores, sendo os únicos que diferiram do controle em praticamente todos os niveis de fosfato parcialmente solubilizado (Tabela 5). Os teores solubilizados por estes fungos, empregando-se o fosfato bruto, foram semelhantes ao encontrado no fosfato $25 \%$ solubilizado em ausência de fungo. Este resultado demonstra que o efeito dos fungos 09 e 60 sobre a fluorapatita bruta equivale ao de $25 \%$ de solubilização pelo ácido sulfúrico. No fosfato $50 \%$ solubilizado, exceto o fungo 09, os demais não diferiram do controle ao nivel de $5 \%$.

0 fungo 25 (Penicillium sp) apresentou 
resultados que não diferiram do tratamento sem fungo em todos os níveis de acidulação do fosfato, exceto o nível $0 \%$

Tabela 5- Teores de fósforo solubilizado por diferentes fungos a partir de fluorapatita com diversos grau de solubilização por $\mathrm{H}_{2} \mathrm{SO}_{4}$ (média de 3 repetições).

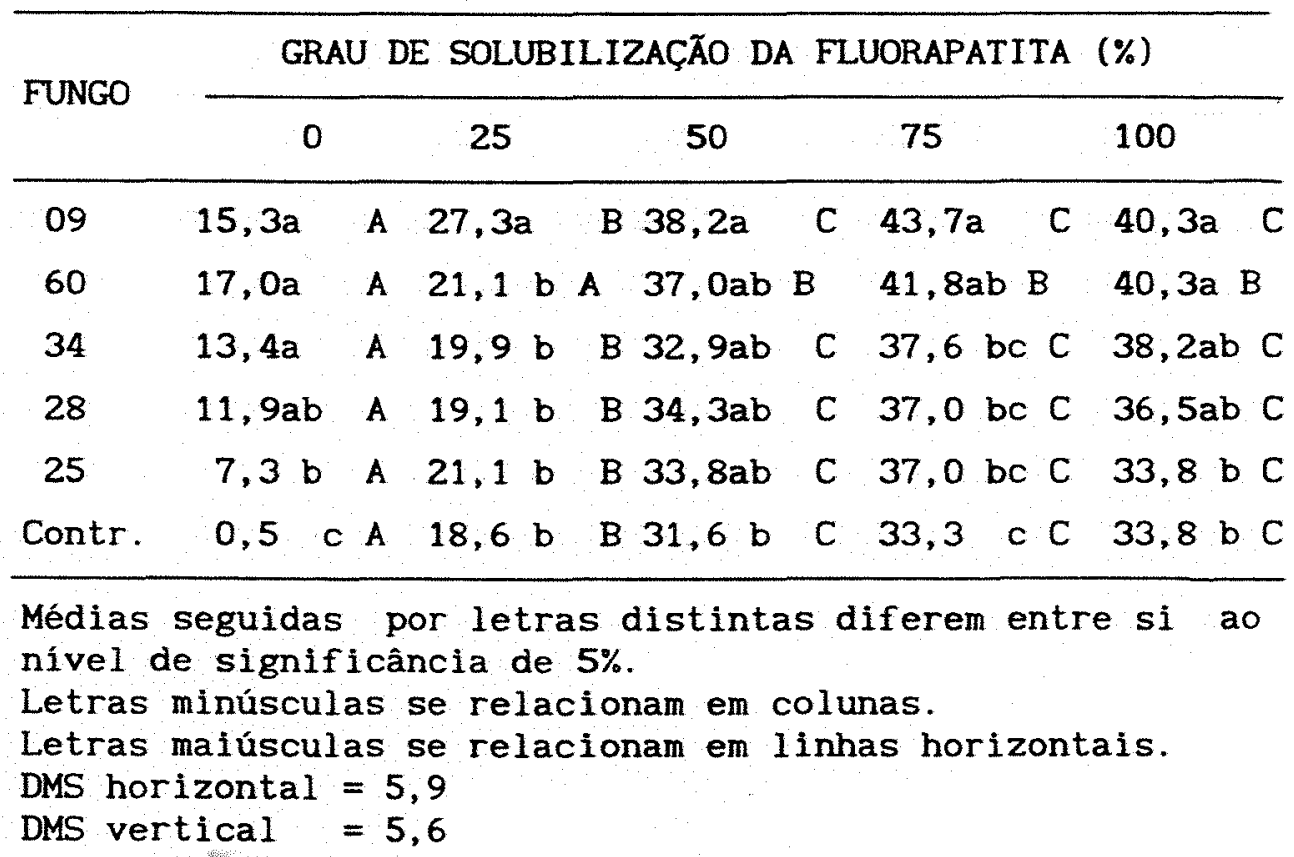

Não foi possivel distinguir a exata contribuição dos componentes biológico e químico na solubilização dos fosfatos acidulados, sobretudo porque houve interação entre os fatores fosfato e fungo. Contudo, é lícito dizer que no tratamento com o melhor fungo (09) e com fosfino $25 \%$ solubilizado, houve um ganho real de fosfato solúvel, em relação ao controle, de aproximadamente $32 \%$, 
contra 17,24 e $16 \%$ nos fosfinos 50,75 e $100 \%$ solubilizados, respectivamente. A Figura 1 ilustra este resultado, mostrando também 0 efeito do segundo melhor solubilizador nestas condições, o fungo 60 . 
40.

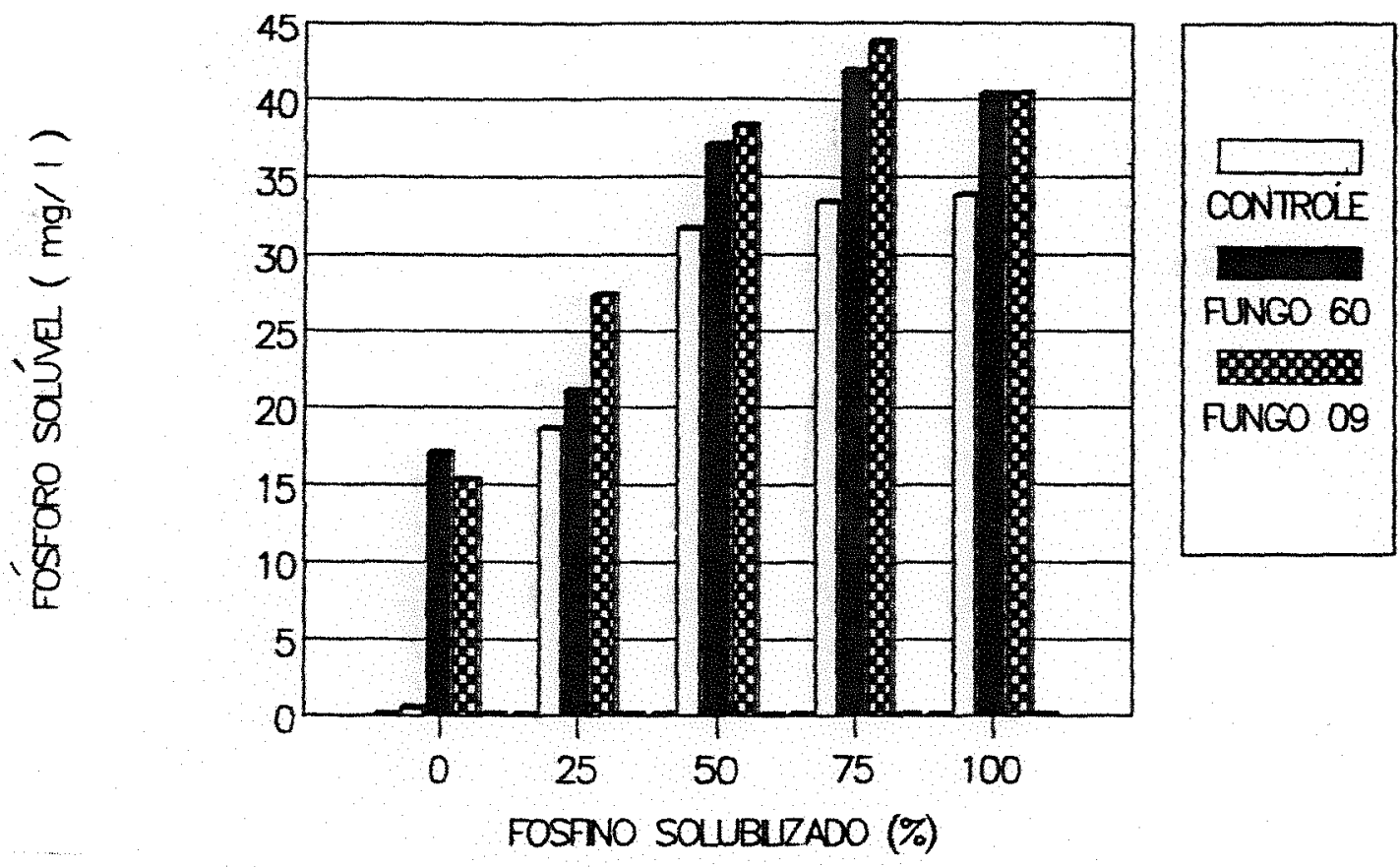

Figura 1 - Efeito dos fungos 09 e 60 (A. niger) sobre a solubilização da fluorapatita com diferentes graus de solubilização em $\mathrm{H}_{2} \mathrm{SO}_{4}$ concentrado. 
Apesar dessa limitação, para se avaliar melhor - efeito do fungo na solubilização, independentemente do efeito do $\mathrm{H}_{2} \mathrm{SO}_{4}$ usado no pré-tratamento do fosfato, foram descontados dos tratamentos com fungo as quantidades de fósforo solubilizadas no respectivo controle. Houve correlação negativa entre as variáveis fósforo solubilizado total (solubilização química e biológica) e pH $\left(\mathrm{r}^{2}=-0,760\right)$, significativa ao nível de $1 \%$ Também para o fósforo solubilizado apenas pelos microrganismos (valores obtidos excluindo-se o efeito do ácido) observou-se correlação negativa entre esta variável e o $\mathrm{pH}\left(\mathrm{r}^{2}=-0,3067\right)$, significativa ao nível de $1 \%$.

Dado o alto preço do ácido sulfúrico no mercado, somente um estudo econômico poderia decidir pela viabilidade do pré-tratamento do fosfino com ácido, para sua posterior solubilização por fungos filamentosos. Mesmo porque - ataque microbiano ao fosfino bruto causou efeito comparável ao do tratamento com ácido ao nível de $25 \%$ de solubilização.

Experimentos para estabelecer a eficiência agronômica utilizando-se fosfino pré-tratado com ácido e microrganismo, ou somente com microrganismo, elucidariam 0 valor prático do processo microbiológico. EIRA (1988), em trabalho de revisão, afirma que "a simples existência de microrganismos solubilizadores de fosfatos e 0 volume crescente de trabalhos in vitro ou em condições muito 
simplificadas, não permite, apesar do seu significado científico, aquilatar as reais possibilidades do processo, quando envolvido no complexo biológico do solo".

Os resultados da variável $\mathrm{pH}$ estão expressos na Tabela 6 . Houve redução significativa do valor de $\mathrm{pH}$, causada pelos fungos. Destes, destacaram-se os de $\mathrm{n}^{\circ} 60$ e 09 (os melhores solubilizadores de fosfato), sendo que o último atingiu os valores mais baixos. Isto ficou evidente no tratamento fosfino bruto, onde, exceto 0 fungo 25 , todos diferiram do controle. (Este resultado está de acordo com a correlação negativa encontrada, neste experimento, entre pH e solubilização de fluorapatita). RAMOS et alii (1968) afirmam que a glicose geralmente estimula a secreção de ácidos orgânicos ${ }^{4}$ E provável que a glìcose, por ser uma molécula prontamente assimilável, tenha favorecido a produção de ácido e o metabolismo como um todo, nos tratamentos com fosfino bruto.

4 Tentou-se fazer uma análise qualitativa, por cromatografia de camada delgada e papel, dos ácidos produzidos. Devido ao baixo teor de ácidos no filtrado, os métodos não apresentaram bons resultados. 
43.

Tabela 6 - Valores de pH do filtrado, obtidos pela inoculação de diferentes fungos, empregando-se fluorapatita com diferentes graus de solubilização em $\mathrm{H}_{2} \mathrm{SO}_{4}$ concentrado (média de 3 repetições).

\begin{tabular}{|c|c|c|c|c|c|c|}
\hline \multirow{3}{*}{$\begin{array}{l}\text { FUNGO } \\
\text { CONTROLE }\end{array}$} & \multicolumn{4}{|c|}{ GRAU DE SOLUBILIZAÇÃO } & \multicolumn{2}{|c|}{ A FLUORAPATITA (\%) } \\
\hline & \multirow{2}{*}{\multicolumn{2}{|c|}{$\frac{0}{4,8 a}$}} & 25 & \multirow{2}{*}{$\frac{50}{3,1 \mathrm{a}}$} & \multirow{2}{*}{$\frac{75}{2,9 a}$} & 100 \\
\hline & & & 3,4 a & & & 2,7 \\
\hline 25 & $4,4=$ & a & $2,9 \mathrm{~b}$ & $2,6 \quad b$ & $2,6 a b$ & 3,3 a \\
\hline 34 & 2,9 & $b$ & 2,7 & $2,7 a b$ & $2,5 a b c$ & 2,5 \\
\hline 28 & 3,0 & $\mathrm{~b}$ & 2,6 & $2,6 \mathrm{~b}$ & $2,5 \mathrm{abc}$ & 2,5 \\
\hline 60 & 2,8 & $b$ & 2,7 & 2,3 & 2,2 bc & 2,0 \\
\hline 09 & 2,7 & $\mathrm{~b}$ & 2,4 & 2,3 & 2,0 & 2,0 \\
\hline
\end{tabular}

Médias seguidas por letras distintas diferem entre si ao nível de significancia de $5 \%$ pelo teste de Tukey.

DMS $=0,5$ 
Para o fungo 25 valor de $\mathrm{pH}$ foi estatisticamente igual ao do controle nos niveis de solubilização 0 e $75 \%$, e menor nos níveis 25 e $50 \%$ No tratamento $100 \%$, contudo, $0 \mathrm{pH}$ do melo contendo 0 fungo 25 foi significativamente maior que todos, superando o controle. Estes resultados, juntamente com a análise de regressão representada na Figura 2 indicam uma tendência de Penicillium sp (cultura 25) em elevar o $\mathrm{pH}$ do meio extremamente ácido. Nesta análise de regessão, confirma-se a tendência dos fungos 60 e 09 (A. niger) em acidificar o meio, independentemente da proporção de $\mathrm{H}_{2 \mathrm{SO}} 4$ utilizada no pré-tratamento da fluorapatita. 


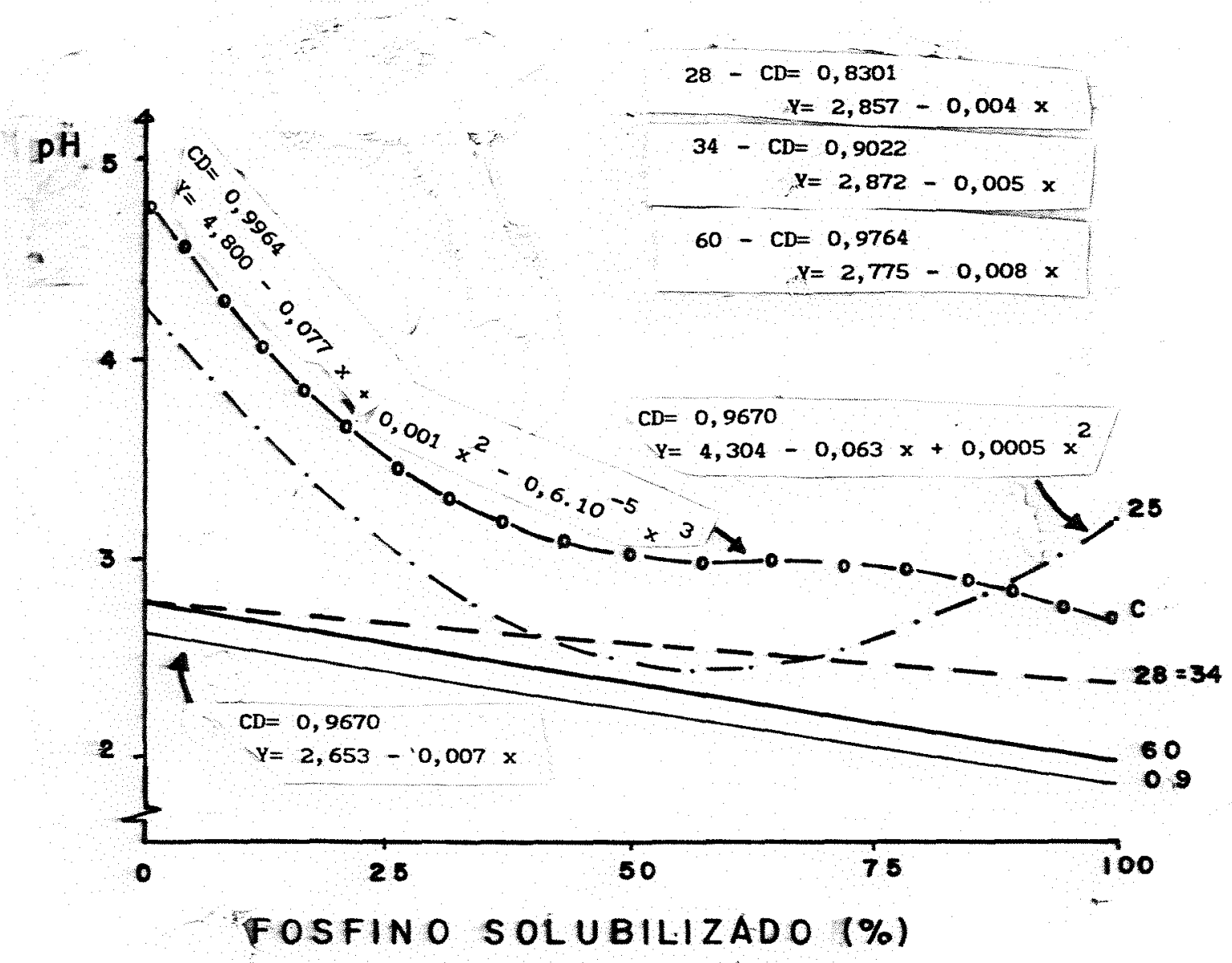

Figura 2 -Variação do $\mathrm{pH}$ em cinco culturas fúngicas e no controle, em relação ao grau de solubilização da fluorapatita por $\mathrm{H}_{2} \mathrm{SO}_{4}$. 
Em função do aumento da concentração de ácido sulfúrico usado no tratamento do fosfino, houve pequena diferença entre os valores de pH observados no controle e fungos 34 (A. niger) e 28.

Os resultados da variável açúcares redutores estão resumidos na Tabela 7 .

Tabela 7 - Concentração de açúcares redutores (mg/ml) do filtrado de cinco fungos, cultivados sob diversos graus de solubilização da fluorapatita por $\mathrm{H}_{2} \mathrm{SO}_{4}$ (média de 3 repetições).

\begin{tabular}{|c|c|c|c|c|c|c|}
\hline \multirow{2}{*}{ FUNGO } & \multicolumn{2}{|r|}{ GRAU } & \multicolumn{2}{|c|}{ DE SOLUBILIZAÇÃO DA } & \multirow{2}{*}{$\frac{\text { FLUORAPATITA }}{75}$} & \multirow{2}{*}{$\frac{(\%)}{100}$} \\
\hline & & 0 & 25 & 50 & & \\
\hline 25 & 40 & a & $60 a$ & $45 a b$ & $67 a$ & $72 a$ \\
\hline 60 & 39 & a & 58 a & 57 a & $53 \mathrm{abc}$ & $66 \mathrm{ab}$ \\
\hline CONTROLE & 52 & $a$ & $51 \mathrm{ab}$ & $46 a b$ & $53 \mathrm{abc}$ & $55 a b$ \\
\hline 34 & 34 & $a$ & $45 a b c$ & $45 a b$ & $36 \quad c$ & $49 \mathrm{~b}$ \\
\hline 28 & 35 & $a$ & $36 \mathrm{bc}$ & $34 \mathrm{~b}$ & $43 \mathrm{bc}$ & $55 \mathrm{ab}$ \\
\hline 09 & 04 & $b$ & $32 c$ & $45 a b$ & $58 \mathrm{ab}$ & $57 a b$ \\
\hline
\end{tabular}

Médias seguidas por letras distintas diferem entre si ao nível de significância de $5 \%$ do teste de Tukey.

DMS $=18,2$ 
Vê-se que para todos os graus de solubilização da fluorapatita por ácido sulfúrico a concentração de açúcares redutores nos filtrados dos fungos 25 e 60 não diferiu estatisticamente da concentração do controle, indicando um balxo consumo de substrato - mesmo tendo o fungo 60 apresentado elevado índice de solubilização neste experimento, juntamente com o fungo 09. A figura 3 ilustra este resultado.

Também para os fungos 25 e 60 , no maior grau de acídifícação observam-se concentrações de açúcares acima das esperadas - a concentração máxima possível, por frasco, seria de $50 \mathrm{mg} / \mathrm{ml}$. Este resultado foi atribuido a erros analíticos (Figura 3 ). 


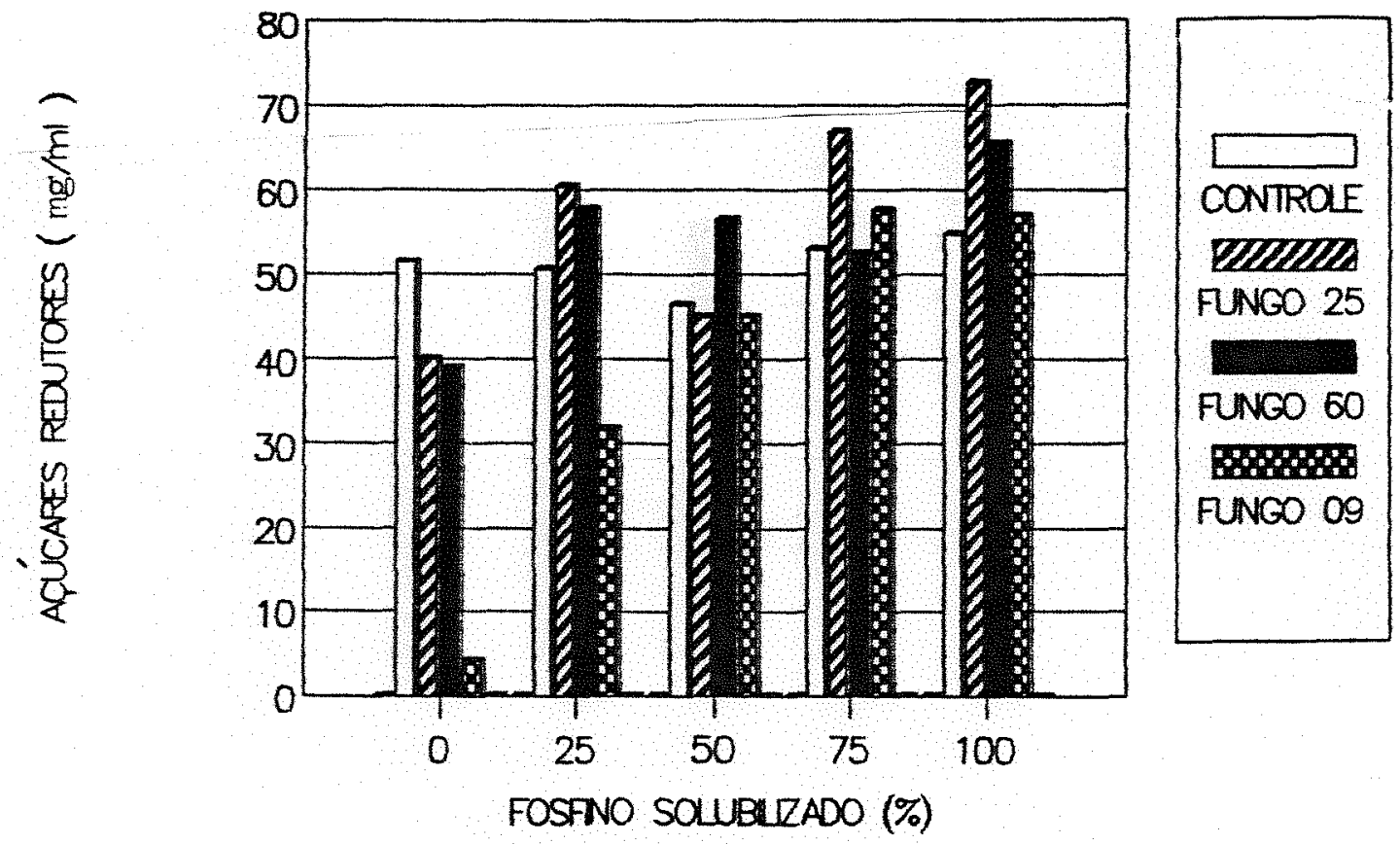

Figura 3 - Concentração de açúcares redutores nos filtrados do controle e fungos 25,60 e 09 , cultivados sob diferentes graus de solubilização da fluorapatita por $\mathrm{H}_{2} \mathrm{SO}_{4}$. 
A análise de regressão (Figura 4) indica que todos os fungos tendem a diminuir o consumo de glicose com o aumento da concentração de ácido sulfúrico utilizado na acidificação do fosfino, provavelmente devido à diminuição de seu metabolismo.

Apesar das restrições quanto à separação do efeito dos componentes químico ( $\left.\mathrm{H}_{2} \mathrm{SO}_{4}\right)$ e biológico, já discutidos, para melhor compreensão dos resultados da variável açúcares redutores os valores destes componentes foram separados. Houve una correlação negativa entre as variáveis açúcares redutores e fósforo solubilizado pelos microrganismos (isto é, descontado o valor solubilizado no controle) significativa ao nivel de $1 \%\left(r^{2}=-0,4378\right)$. o mesmo não aconteceu em relação ao fósforo solubilizado biológica e quimicamente: houve correlação positiva $\left(r^{2}=0,3601\right)$ entre os valores absolutos de fosfóro solubilizado e concentração de açúcares redutores, o que foi atribuido principalmente ao efeito do $\mathrm{H}_{2} \mathrm{SO}_{4}$. A primeira correlação poderia indicar que o aumento da atividade solubilizadora do microrganismo é acompanhada de um aumento do consumo de glicose, o que foi claramente observado no cultivo do fungo 09 . Contudo, 0 fungo 60 pouco consumiu, apesar de ter solubilizado equivalente quantidade de fosfato, demonstrando, portanto, maior eficiência. 


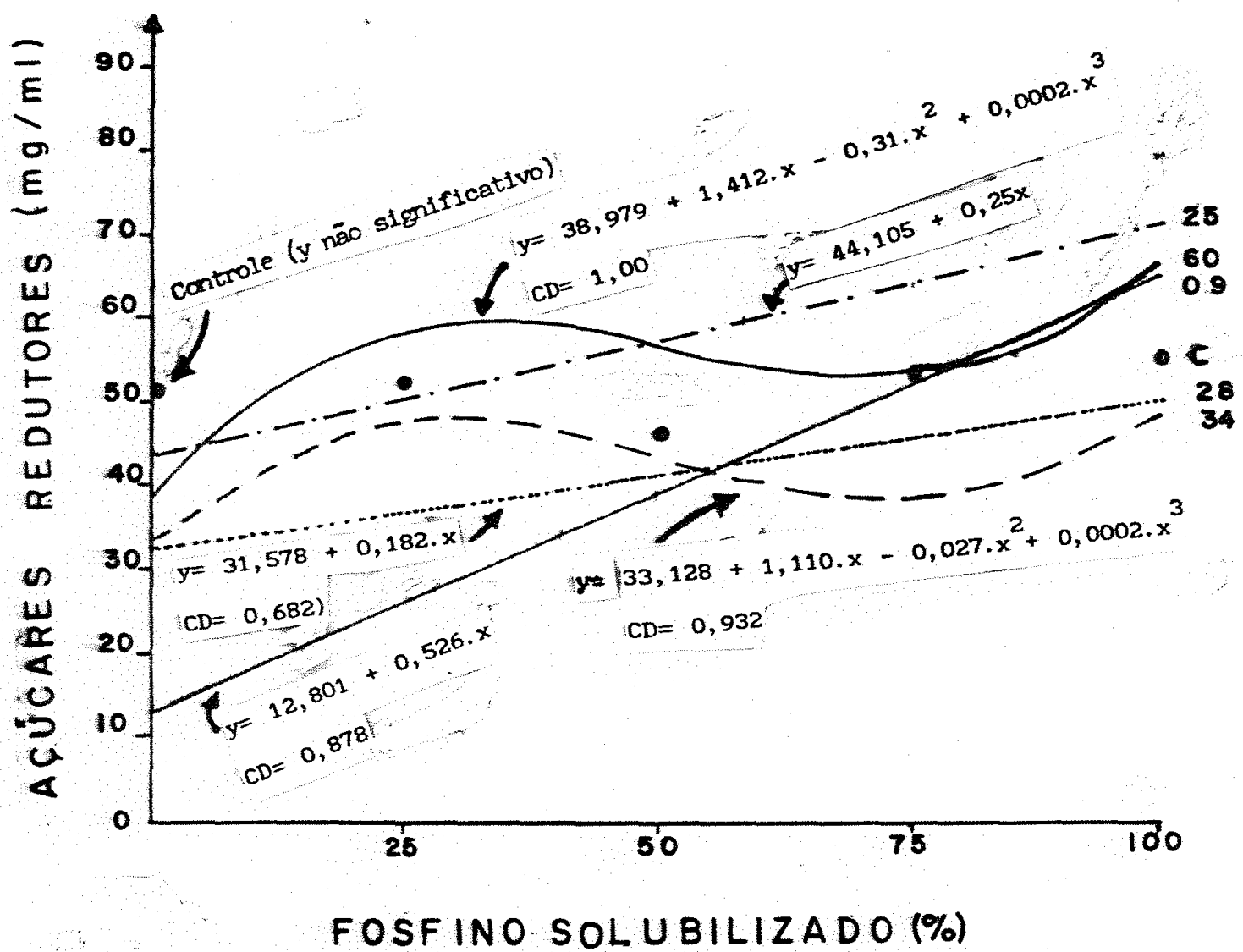

Figura 4 - Variação da concentração de açúcares redutores do filtrado do controle e das culturas $25,60,09$, 28 e 34 , em relação ao grau de solubilização fluorapatita por $\mathrm{HaSO}_{4}$. 
Com relação à análise cristalográfica, a técnica utilizada permite obter bons difratogramas.

Os produtos cristalinos formados para cada tratamento do fosfino com ácido sulfúrico e com microrganismo estão listados na Tabela 8.

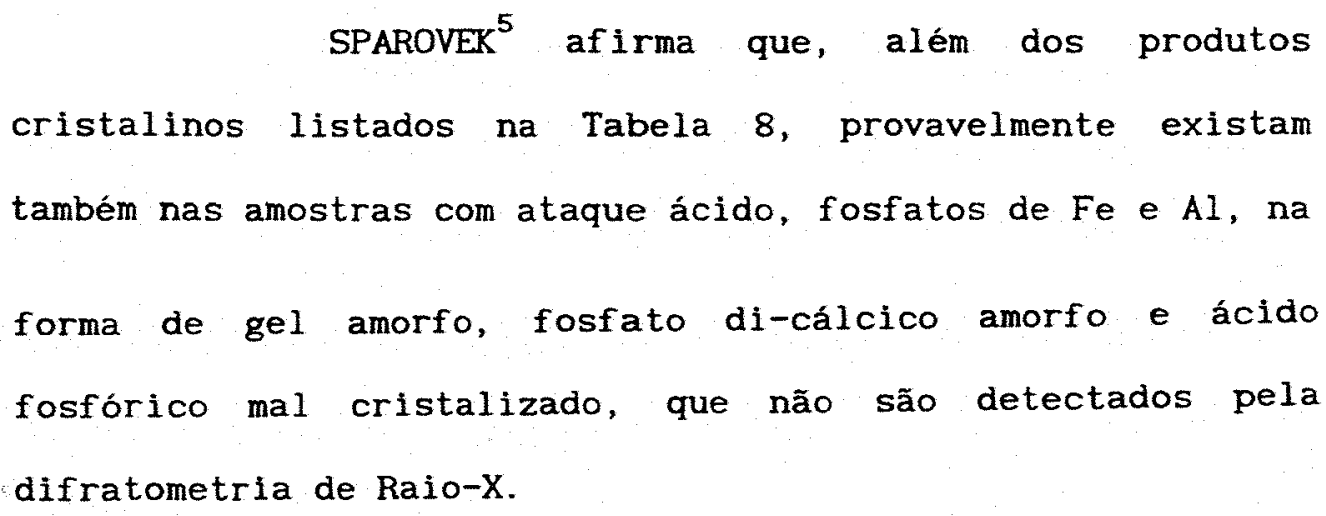

5 SPAROVEK, G. (ESALQ, Departamento de Solos, Geologia e Fertilizantes). Comunicação pessoal, 1988, 
Tabela 8 - Análise cristalográfica da fluorapatita bruta, parcialmente solubilizada por A. niger (cultura 34) e por $\mathrm{H}_{2} \mathrm{SO}_{4}$.

\begin{tabular}{cccc}
\hline $\begin{array}{c}\text { TRATAMENTO } \\
\text { (em \% de } \\
\text { solubilização) }\end{array}$ & $\begin{array}{c}\text { Ca5F (PO4) } \\
\text { (FLUORAPATITA) }\end{array}$ & $\begin{array}{c}\mathrm{CaHPO}_{4} \\
\text { (BRUXITA) }\end{array}$ & $\begin{array}{c}\mathrm{CaSO}_{4} \\
\text { (ANIDRITA) }\end{array}$ \\
\hline 0 (bruto) & + & - & - \\
25 & + & + & + \\
50 & + & + & + \\
75 & + & + & + \\
100 & + & + & - \\
$0+$ fungo 34 & + & + & + \\
\hline
\end{tabular}

$(+)=$ presença de

$(-)=$ ausência de

Observou-se que: (a) mesmo com o ataque com ácido sulfúrico para se obter supostos $100 \%$ de solubilização do fosfino, não ocorreu a dissolução completa da fluorapatita; (b) os produtos cristalinos formados são $\mathrm{CaHPO}_{4}$ 
e $\mathrm{CaSO}_{4}$, sendo que CasF $\left(\mathrm{PO}_{4}\right)_{3}$ é componente típico do fosfino em estado natural; (c) com o aumento da concentração de ácido, o grau de cristalinidade do residuo diminuiu, indicando o surgimento de formas amorfas.

Visto que para o fosfino bruto sob cultivo do fungo 34 observou-se apenas fluorapatita no difratograma, admite-se duas hipóteses: (a) não está havendo dissolução da fluorapatita; (b) a dissolução está ocorrendo, mas o raio-x não está detectando a quantidade solubilizada, ou os produtos de dissolução estão se recombinando em formas amorfas (gel, fosfato di-cálcico). A segunda hipótese é mais plausível, pois os resultados obtidos neste experimento por fotocolorimetria demonstraram que houve solubilização significativa causada pelo fungo 34 ( $A$. niger), e a amostra analisada não poderia reter todo o fósforo solúvel durante a filtragem.

4.3. Efeito de dose de fosfato, fungo tempo de cultivo na solubilização da fluorapati ta bruta - EXPERIMENTo 3

Verificou-se que os teores de fósforo solúvel e os valores de $\mathrm{pH}$ encontrados no filtrado, bem como a produção de biomassa fúngica, dependeram da dose de fosfato, do fungo e do tempo de cultivo empregados. O fator 
dose interagiu com o fator fungo, e fungo com tempo, tanto para a variável pH, quanto para fósforo solúvel; mas tempo de cultivo e dose não interagiram. Somente para fósforo solubilizado houve interação tripla (Tabela 9).

Tabela 9 - Análise da variâncla para fósforo solubilizado, pH e biomassa.

\begin{tabular}{|c|c|c|c|c|}
\hline \multirow{2}{*}{ C.V. } & \multirow{2}{*}{ G.L. } & \multicolumn{3}{|c|}{ Q.M. } \\
\hline & & FÓSFORO & $\mathrm{pH}$ & BIOMASSA \\
\hline Dose & 3 & $82,47^{* *}$ & $0,16^{* *}$ & $40,66^{* *}$ \\
\hline Fungo & 2 & $4.199,90^{* *}$ & $59,56^{* *}$ & $1,04^{* *}$ \\
\hline $\begin{array}{l}\text { Tempo de } \\
\text { Cultivo }\end{array}$ & 3 & $3.060,25^{* *}$ & $10,55^{* *}$ & $0,83^{* *}$ \\
\hline Dose $\times$ Fungo & 6 & $26,49^{*}$ & $0,22^{*}$ & $0,08 n . s$. \\
\hline Dose $\times$ Tempo & 9 & 9,81 n.s. & 0,05 n.s. & $0,08 \mathrm{n} . \mathrm{s}$. \\
\hline Fungo $x$ Tempo & 6 & $932,46^{* *}$ & $1,11^{* *}$ & $0,34 \mathrm{n} . \mathrm{s}$. \\
\hline $\begin{array}{l}\text { Dose } x \text { Fungo } x \\
\text { Tempo }\end{array}$ & 18 & $16,03^{*}$ & $0,03 \mathrm{n} . \mathrm{s}$ & $0,07 \mathrm{n} . \mathrm{s}$. \\
\hline Resíduo & 96 & 7,24 & 0,03 & 0,11 \\
\hline Total & 143 & & & \\
\hline $\begin{array}{l}\text { C.V. }= \\
(* *)=\text { signific }\end{array}$ & & $\begin{array}{l}24,5 \% \\
\text { nível de } 1 \%\end{array}$ & $\begin{array}{l}\text { 4, } 3 \% \\
\text { de probab }\end{array}$ & $\begin{array}{l}18,8 \% \\
\text { lade. }\end{array}$ \\
\hline
\end{tabular}

Não houve solubilização significativa até 2 dias de cultivo (Tabela 10). Aos 7 dias foi observada solubilização significativa nos tratamentos fungo 25 
(Penicillium sp), em todas as doses, e fungo 34 (A. niger) nas doses 2 e $3 \mathrm{~g}$ de fosfato. Aos 14 e 21 dias os dois fungos diferiram do controle em todas as doses.

Tabela 10 - Teores de fósforo solubilizado por fungos em relação ao tempo de coleta e à dose de fosfino utilizada (média de 3 repetições).

\begin{tabular}{|c|c|c|c|c|c|}
\hline \multirow{2}{*}{ DOSE $(\mathbf{g})$} & \multirow{2}{*}{ FUNGO } & \multicolumn{4}{|c|}{ TEMPO (dias) } \\
\hline & & 2 & 7 & 14 & 21 \\
\hline \multirow{3}{*}{0,5} & 34 & 0,6 a & $3,2 \quad b$ & $20,7 a$ & 34,4 a \\
\hline & 25 & $0,2 a$ & $10,5 \mathrm{a}$ & $20,1 \mathrm{a}$ & $22,3 \quad b$ \\
\hline & Controle & 0,1 a & $0,4 \quad b$ & $0,3 \mathrm{~b}$ & 0,3 \\
\hline \multirow{3}{*}{1,0} & 34 & $1,2 a$ & $3,6 \quad b$ & $21,9 \mathrm{a}$ & $40,5 \mathrm{a}$ \\
\hline & 25 & $0,2 a$ & 12,2 a & $21,3 \mathrm{a}$ & 21,7 \\
\hline & C & $0,2 a$ & $0,4 \quad b$ & $0,2 \quad b$ & 0,3 \\
\hline \multirow{3}{*}{2,0} & 34 & $4,0 \mathrm{a}$ & 7,1 a & $24,3 \mathrm{a}$ & 39,1 a \\
\hline & 25 & $0,2 \mathrm{a}$ & $11,7 \mathrm{a}$ & $25,0 \mathrm{a}$ & 23,2 \\
\hline & $\mathrm{C}$ & $0,3 a$ & $0,3 b$ & $0,3 \mathrm{~b}$ & 0,3 \\
\hline \multirow{3}{*}{3,0} & 34 & $3,0 a$ & $11,6 \mathrm{a}$ & 24,8 a & $38,9 \mathrm{a}$ \\
\hline & 25 & $0,1 \mathrm{a}$ & 13,5 a & $26,2 \mathrm{a}$ & 36,3 a \\
\hline & $\mathrm{C}$ & $0,3 a$ & $0,3 \mathrm{~b}$ & 0,2 & 0,3 \\
\hline
\end{tabular}

Médias seguidas por letras distintas diferem entre si ao nível de $5 \%$ de significancia pelo teste de Tukey.

DMS $=5,2$ 
Observa-se alnda na Tabela 10 que nas doses $0,5,1,0$ e $2,0 \mathrm{~g} \circ$ fungo 34 solubilizou aproximadamente 54 , 100 e $70 \%$ mais que o fungo 25 , respectivamente, aos 21 dias. Na dose $3,0 \mathrm{~g}$, contudo, os resultados de ambos se equivaleram, independentemente do tempo de cultivo. 0 aumento da atividade solubilizadora, devido ao emprego de maior dose, também foi notado aos 7 dias, na cultura 34, apesar de que este efeito não se verificou nas coletas subsequentes, demonstrando que nestas condições 0 aumento do tempo de cultivo do fungo 34 (A. niger) supera o efeito aditivo de doses altas.

A análise de regressão (Figura 5) sugere que, nas condições deste experimento, A. niger (fungo 34) tende a iniciar a solubilização nas primeiras 48 horas, antes de Penicillium sp (fungo 25), mas numa velocidadeinferior, a ponto de ser superado aos 7 dias de cultivos. A análise confirma que o tempo de cultivo prolongado beneficia o fungo 34: aos 14 dias a quantidade de fósforo solubilizado é semelhante para ambos, e aos 21 dias $A$. niger (34) novamente apresenta maior quantidade de fósforo solubilizado que Penicillium sp (25).

No controle não ocorreu qualquer solubilização até o fim do experimento (Figura 5), sendo os valores de fósforo solúvel observados atribuidos ao resíduo solúvel encontrado no fosfino bruto. 
57.

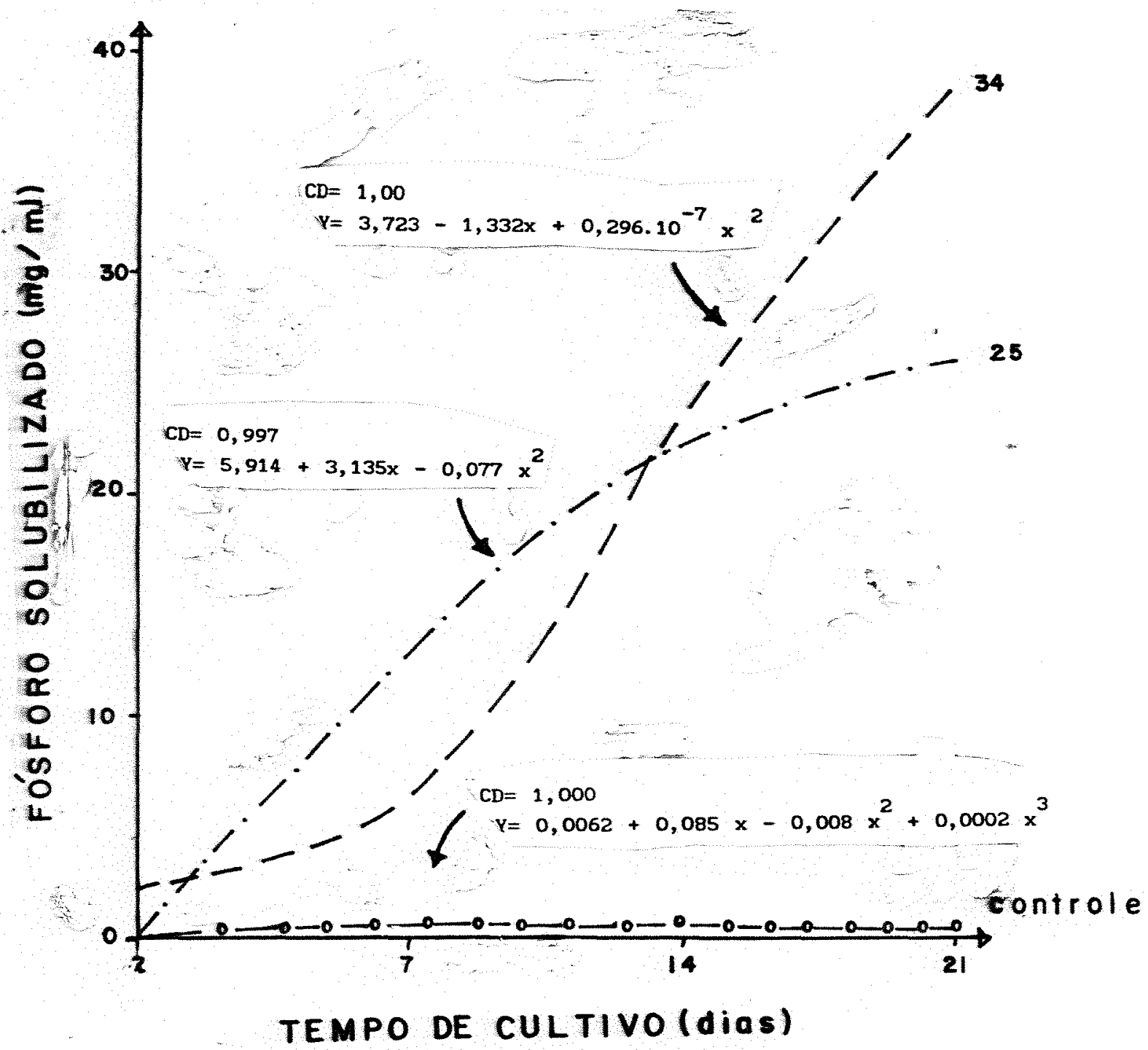

Figura 5 - Fósforo solubilizado pelos fungos 34 (A. niger) e 25 (Penicillium sp.), em relação ao tempo de cultivo. 
Com relação à influência das doses de fosfato sobre a variação de $\mathrm{pH}$, somente 0 controle apresentou diferenças estatísticas significativas: houve uma elevação de pH de 5,0 para 5,5 com o aumento da quantidade de fosfíno no meio estéril. A cultura 25 apresentou valores próximos a 4,1 , enquanto que a 34 , próximos a 3,0 (média de quatro tempos de cultivo).

A análise de regressão (Figura 6) indica que o fungo 34 (A. niger) apresentou os mais baixos valores de $\mathrm{pH}$, diferindo do controle em 2,5 unidades ao término do experimento; após $014^{\circ}$ dia este fungo tende a manter o pH na faixa 2,7 .

o fungo 25 apresentou valores intermediários entre 0 fungo 34 e 0 controle; destaca-se na Figura $6 \circ$ decréscimo acentuado dos valores de $\mathrm{pH}$ para este fungo, o qual apresentou 0,4 unidades de $\mathrm{pH}$ abaixo do controle, aos 2 dias, aumentando esta diferença para 1,5 unidade ao término do experimento. Nota-se que $\circ \mathrm{pH}$ do controle tende a cair desde $02^{\circ}$ até $014^{\circ}$ dia. 


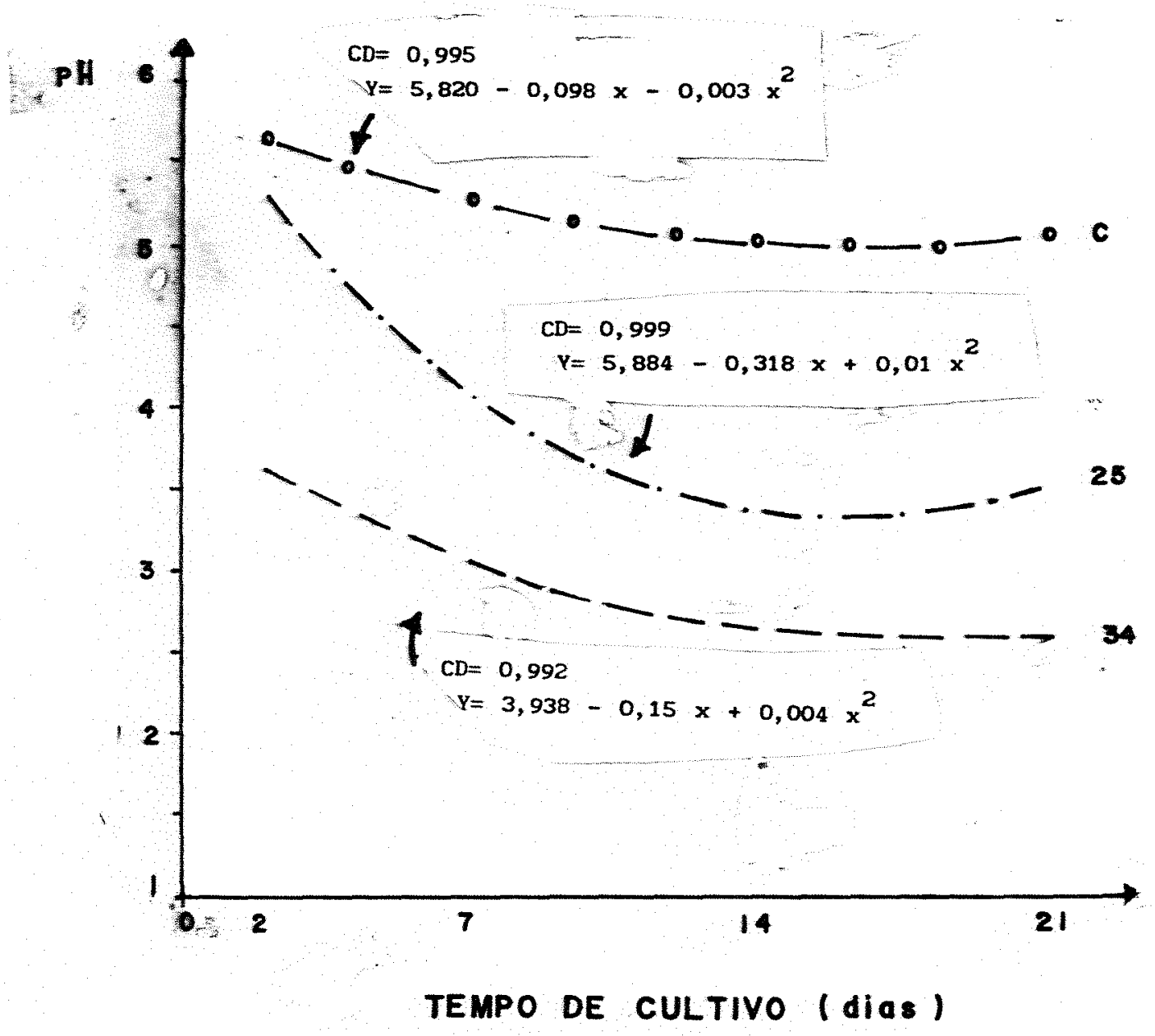

Figura 6 - Variação do pH nas culturas 25,34 e no controle, em relação ao tempo de cultivo. 
Houve correlação negativa e significativa entre pH e fósforo solubilizado $\left(r^{2}=-0,77\right)$.

Quanto à produção de biomassa, após 21 dias de cultivo o fungo 34 produziu $0,4891 \mathrm{~g}$ e $\circ 25,0,4503 \mathrm{~g}$. Ambos diferiram do controle, sendo que Penicillium sp (fungo 25) apresentou crescimento significativo a partir do $7^{\circ}$ dia. Não houve correlação entre biomassa fúngica e $\mathrm{pH}\left(\mathrm{r}^{2}=\right.$ -0,11). Porém, biomassa fúngica correlacionou-se positivamente com a variável fósforo solubilizado $\left(\mathrm{r}^{2}=\right.$ $0,28)$

4.4. Solubilização biológica do fosfato, aplicado em doses crescentes, em diferentes períodos de cultivo, utilizando-se vinhaça esterilizada EXPERIMENTO 4.

A análise da variância demonstrou que, para a variável fósforo solubilizado, houve interação significativa entre os fatores tempo de cultivo, dose de fosfato e fungo (Tabela 11). As doses, por si só, não causaram efeito no teor de fósforo solubilizado, mas influiram no pH. Com relação ao $\mathrm{pH}$, todos os fatores o influenciaram, mas não houve interação significativa entre eles. 
Tabela 11 - Análise da variância para fósforo solubilizado e pH.

\begin{tabular}{|c|c|c|c|}
\hline \multirow{2}{*}{ C.V. } & \multirow{2}{*}{ G.L. } & \multicolumn{2}{|c|}{ Q.M. } \\
\hline & & FÓSFORO & $\mathrm{pH}$ \\
\hline Tempo de cultivo & 2 & $44,48^{* *}$ & $1,13^{* *}$ \\
\hline Doses & 2 & 6,90 n.s. & $0,67^{* *}$ \\
\hline Fungo & 3 & $1.150,67^{* *}$ & $5,84^{* *}$ \\
\hline T. cultivo $x$ Dose & 54 & $8,13^{*}$ & 0,04 n.s. \\
\hline Doses $x$ Fungo & 6 & $19,82^{* *}$ & $0,06 \mathrm{n.s}$. \\
\hline $\begin{array}{l}\text { T. cultivo } \times \text { Dose } \\
\times \text { Fungo }\end{array}$ & 12 & $5,62^{*}$ & $0,04 \mathrm{n} . \mathrm{s}$. \\
\hline Resíduo & 78 & 3,32 & 0,07 \\
\hline Total & 107 & & \\
\hline $\begin{array}{l}\mathrm{C} . \mathrm{V} .= \\
(*)=\text { significati } \\
(* *)=\text { significat }\end{array}$ & $\begin{array}{l}\text { vo ao } \\
\text { ivo a }\end{array}$ & $\begin{array}{l}13,9 \% \\
\text { de } 5 \% \\
1 \text { de } 1 \%\end{array}$ & $5,5 \%$ \\
\hline
\end{tabular}

o teor de fósforo solubilizado aumentou com o tempo de cultivo. 0 teste de Tukey (Tabela 12) indica que este aumento deveu-se aos fungos 60 (A. niger) e 25 (Penicillium sp) nas doses 0,5 e 1,0 . Este resultado credita-se também o efeito das interações, percebido na análíse da variância. 
A Tabela 12 demonstra também que houve um decréscimo no teor de fosfato solubilizado pelo fungo 25 após o $20^{\circ}$ dia, na dose $3,0 \mathrm{~g}$, não diferindo do controle ao término do experimento. No cômputo geral este fungo fol 02 melhor solubilizador, solubilizando mals aos 20 e 42 dias. 0 fungo 60 solubilizou mais aos 42 dias. Já o fungo 34 ( $A$. niger) igualou-se ao fungo 25, aos 12 dias. Porém, aos 20 e 42 dias, exceto na dose $1,0 \mathrm{~g}$, igualou-se ao controle, sendo, portanto, o fungo que menos solubilizou. Para este fungo maiores teores de fósforo solubilizado foram encontrados nas doses 2,0 e $3,0 \mathrm{~g}$, aos 20 e 42 dias de cultivo.

Estes resultados apontam uma diferença de comportamento entre os fungos 25 e 34 : o primeiro parece solubilizar mais em baixas doses de fosfino, enquanto o segundo parece fazê-1o em doses mais elevadas.

A Tabela 12 demonstra ainda que 0 fungo 60 apresentou os maiores teores de fósforo solubilizado em todas as doses e tempos de cultivo. No cômputo geral este apresentou, aproximadamente, 3,5 vezes mais fósforo solúvel que o controle. 
Tabela 12 - Teores de fósforo solubilizado por fungos (mg/l) em diversos tempos de cultivo e doses de fosfino (média de 3 repetições).

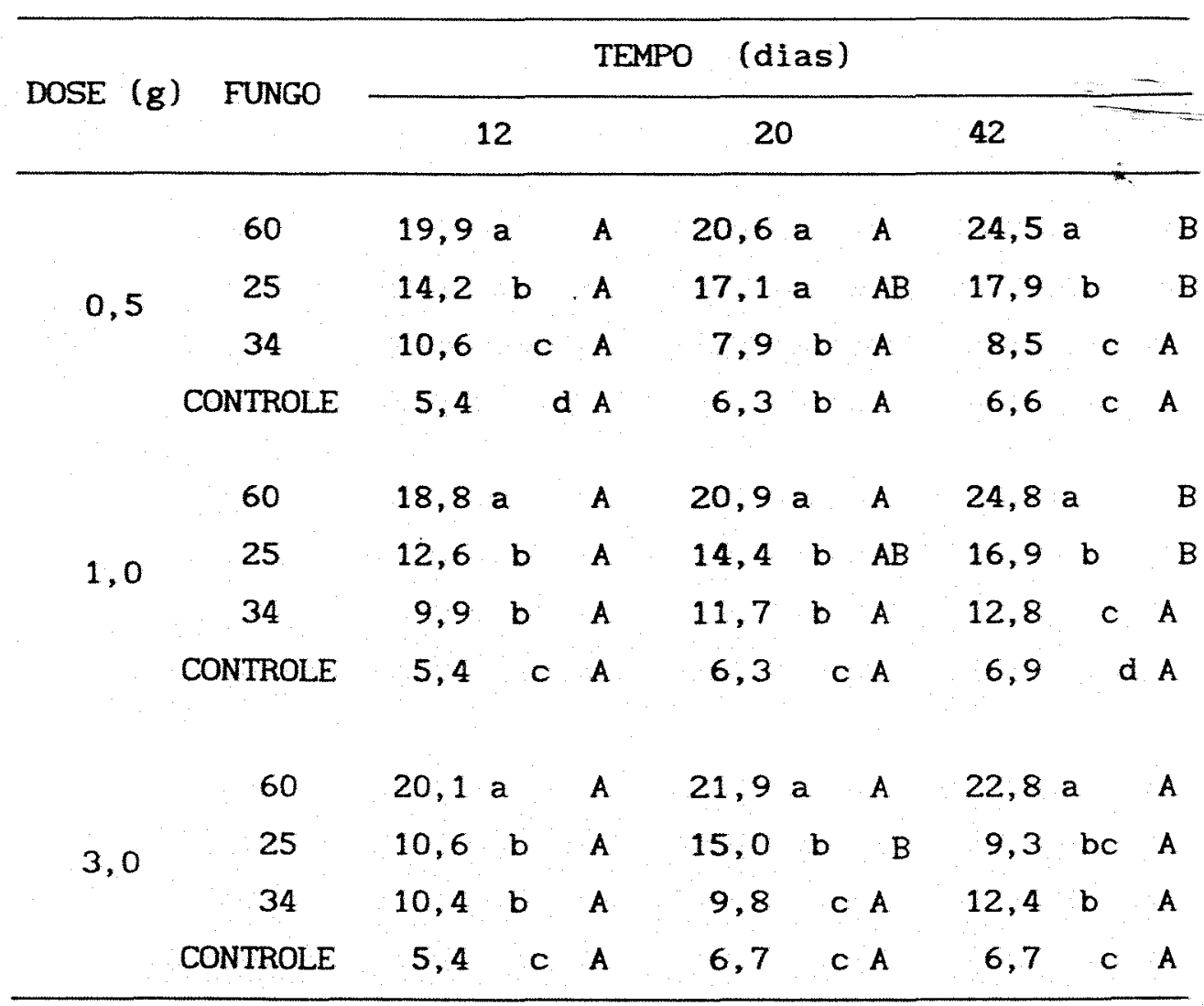

Médias seguidas por letras distintas diferem entre si ao nivel de significância de $5 \%$.

Letras maiúsculas se relacionam na horizontal. Letras minúsculas se relacionam na vertical.

DMS vertical $=3,6$

DMS horizontal $=3,2$ 
Em relação ao tempo de cultivo, a análise de regressão sugere que o fungo 25 apresenta una tendência a solubilizar mais fosfato por volta do $20^{\circ}$ dia; aos 42 dias apresenta a mesma quantidade de fósforo solúvel encontrada no $12^{\circ}$ dia, devido ao mencionado efeito da dose $3,0 \mathrm{~g}$, enquanto que os demais e o controle tendem a elevar o teor de fósforo solúvel no decorrer do tempo (Figura 7).

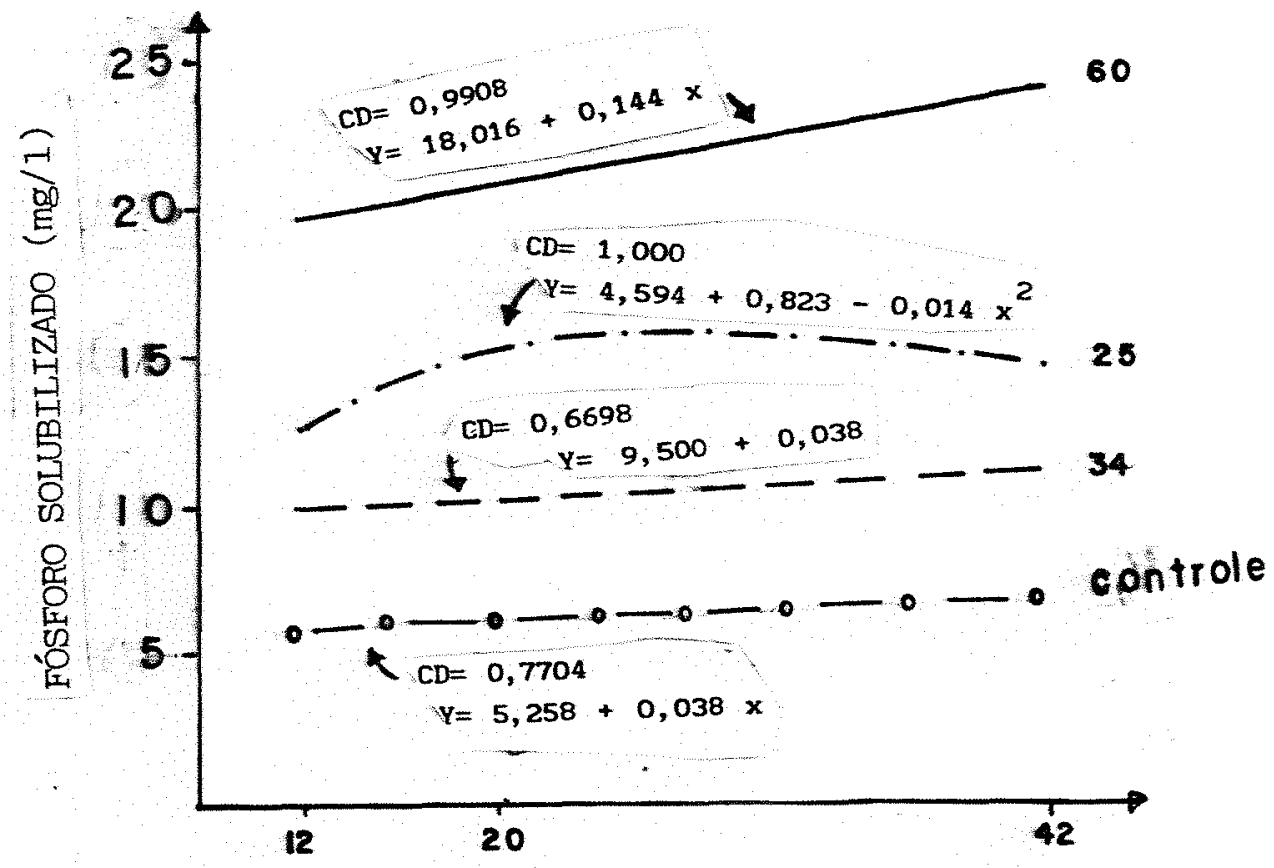

\section{TEMPO DE CULTIVo (dias)}

Figura 7 - Fósforo solubilizado pelos fungos 60,25 e 34 , em relação ao tempo de cultivo. 
Quanto aos valores de $\mathrm{pH}$ observados, a análise da variancia (Tabela 11), e o teste de Tukey (Tabela 12) mostram : que houve diferenças significativas dentro dos fatores fungo, tempo de cultivo e dose, mas não houve quaisquer interações entre eles.

As equações de regressão e os coeficientes de determinação mostraram que as variações de $\mathrm{pH}$ tendem a uma regressão linear.

4.5. Mineralização do fósforo orgânico e solubilização do fosfato bruto em vinhaça natural, em ausência e presença de fungos selecionados - EXPERIMENTO 5

Na Tabela 13 percebe-se que houve diferenças signficativas entre os tratamentos, com relação aos parâmetros fósforo e pH. Os coeficientes de variação indicam que o erro experimental está dentro dos limites aceitáveis para este experimento.

- tratamento "com fluorapatita e fungo 60 ( $A$. niger)" foi o único que diferiu dos demais, apresentando 2,5 vezes mais fósforo solúvel que o controle "com fluorapatita sem fungo selecionado"; também fol o único em que o pH atingiu valores abaixo de 8,0 (Tabela 14). EIRA, \& CARVALHO 
(1971) sugeriram que, na solubilização do fósforo em $\mathrm{pH}$ alcalino, há incorporação deste elemento à biomassa microbiana e posterior liberação.

Tabela 13 - Análise da variância para fósforo solubilizado e $\mathrm{pH}$.

\begin{tabular}{cccc}
\hline & & \multicolumn{2}{c}{ Q.M. } \\
\cline { 3 - 4 } & G.L. & FÓSFORO & pH \\
\hline Tratamento & 5 & $239,17^{* *}$ & $3,03^{* *}$ \\
Resíduo & 21 & 11,70 & 0,12 \\
\hline Total & 26 & & \\
\hline C.V. $=$ & & 26,2 & 4,1
\end{tabular}

$(* *)=$ significativo ao nível de $5 \%$.

Assim, não se pode descartar a possibilidade de que tenha havido maior solubilização da fluorapatita pelos fungos 25 (Penicillium sp) e 34 (A. niger), ou mesmo pela microbiota nativa e substâncias próprias da vinhaça e concomitante incorporação do fósforo às estruturas celulares 
destes fungos.

Não houve interferência do fósforo da própria vinhaça nos resultados: a tabela 14 sugere que, na vinhaça sem fosfino, inoculada com o fungo 34 (A. niger), houve uma pequena mineralização do fósforo orgânico do substrato ( $1,4 \mathrm{mg} / 1$, comparando-se com o controle "vinhaça natural sem fluorapatita e fungos selecionados"), mas este efeito não foi detectado pelo teste de Tuckey no limite de $5 \%$ de probabilidade. Um ensaio incluindo o fungo 60 como inóculo para vinhaça sem fosfino, uma análise da biomassa microbiana e um controle absoluto (vinhaça esterilizada, sem fluorapatita) melhor esclareceria a mineralização do fósforo orgânico da vinhaça pelos fungos, visto que nas condições deste experimento 0 fungo 34 não consegue solubilizar o fosfato de rocha,e o papel da microbiota nativa na mineralização da vinhaça natural livre de fluorapatita não foi suficientemente quantificado. 
68.

Tabela 14 - Efeito da introdução de fungos selecionados e fluorapatita sobre os teores de fósforo solubilizado e valores de $\mathrm{pH}$ da vinhaça natural (média de 3 repetições).

\begin{tabular}{|c|c|c|c|}
\hline TRATAMENTO & $\begin{array}{c}\text { FOSFORO } \\
\text { SOLUBILIZADO }(\mathrm{mg} / 1)\end{array}$ & & $\mathrm{pH}$ \\
\hline$P_{1} F_{1} \quad(60)$ & 26,9 a & 6,8 & $\mathbf{a}$ \\
\hline $\mathrm{P}_{1} F_{0}$ & $10,9 \quad b$ & 8,6 & $\mathrm{~b}$ \\
\hline$P_{1} F_{1} \quad(34)$ & $10,6 \quad b$ & 8,7 & $\mathrm{~b}$ \\
\hline $\mathrm{PoF}_{1}$ (34) & 9,9 b & 8,9 & $b$ \\
\hline$P_{1} F_{1}$ & $9,1 \mathrm{~b}$ & 8,7 & $\mathrm{~b}$ \\
\hline PoFo & $8,5 \quad b$ & 8,8 & $\mathrm{~b}$ \\
\hline
\end{tabular}

Médias seguidas por letras distintas diferem entre si ao nível de $5 \%$ pelo teste de Tukey.

$P=$ fosfino

$F=$ fungo selecionado - cultura entre ( )

$1=$ presença de

o = ausência de 


\subsection{Solubilização do fosfato bruto utilizando-se fungos selecionados, vinhaça natural e esterilizada - EXPERIMENTO 6}

Houve diferenças entre os tratamentos, tanto para a variável fósforo quanto para pH (Tabela 15).

$$
\begin{gathered}
\text { Tabela } 15 \text { - Análise da variâncla para fósforo } \\
\text { solubilizado e } \mathrm{pH} .
\end{gathered}
$$

\begin{tabular}{lccc}
\hline & & & Q.M. \\
\cline { 3 - 4 } C.V. & G.L. & FOSFORO & $\mathrm{pH}$ \\
\hline Tratamento & 7 & $224,48^{* *}$ & $13,23^{* *}$ \\
Resíduo & 24 & 10,33 & 0,11 \\
\hline Total & 31 & & \\
\hline C.V. $=$ & & $21,8 \%$ & $4,8 \%$ \\
** $^{*}=$ significativo ao nivel de $1 \%$. &
\end{tabular}

Dentre os três fungos selecionados, o fungo 60 ( $A$. niger) foi o único que solubilizou quantidades significativas da fluorapatita tanto em vinhaça esterilizada quanto em vinhaça natural: 3,6 e 2,5 vezes mais que 0 controle, 
respectivamente. Esta cultura mostrou ainda ser capaz de elevar $\circ \mathrm{pH}$ de 4,2 para 5,5, na vinhaça esterilizada, e abaixá-10 de 8,6 para 6,8 , na vinhaça natural. Estes resultados demonstram grande capacidade deste fungo de adptar-se ao meio em relação aos demais (Tabela 16).

Tabela 16 - Efeito da introdução de fungos selecionados sobre a solubilização de fluorapatita e pH em vinhaça natural e esterilizada (média de 3 e 5 repetições).

\begin{tabular}{lcll}
\hline TRATAMENTO & $\begin{array}{c}\text { FOSFORO SOLUBILIZADO } \\
\text { (mg/l) }\end{array}$ & \multicolumn{2}{c}{$\mathrm{pH}$} \\
\hline $\mathrm{VnF}_{1}(60)$ & $26,9 \mathrm{a}$ & $6,8 \mathrm{~b}$ \\
$\mathrm{VeF}_{1}(60)$ & $24,8 \mathrm{ab}$ & 5,5 & $\mathrm{c}$ \\
$\mathrm{VeF}_{1}(25)$ & $16,9 \mathrm{bc}$ & 4,9 & $\mathrm{~cd}$ \\
$\mathrm{VeF}_{1}(34)$ & $12,8 \mathrm{~cd}$ & 5,4 & $\mathrm{c}$ \\
$\mathrm{V}_{\mathrm{nF}}$ & $10,9 \mathrm{~cd}$ & $8,6 \mathrm{a}$ \\
$\mathrm{VnF}_{1}(34)$ & $10,6 \mathrm{~cd}$ & $8,7 \mathrm{a}$ \\
$\mathrm{VnF}_{1}(25)$ & $9,1 \mathrm{~cd}$ & $8,7 \mathrm{a}$ \\
$\mathrm{VeF}_{0}$ & $6,9 \mathrm{~d}$ & 4,2 & $\mathrm{~d}$ \\
\hline
\end{tabular}

Médias seguidas por letras distintas diferem entre si ao nível de $5 \%$ de significância, pelo teste de Tukey.

$V_{e}=$ vinhaça esterilizada

$V_{n}=$ vinhaça natural

$F_{1}=$ presença de fungo selecionado - cultura entre ( )

Fo = ausência de fungo selecionado 
Os fungos 25 e 34 elevaram $0 \mathrm{pH}$ da vinhaça esterilizada a valores semelhantes ao do fungo 60 . No entanto, não solubilizaram tanto fosfato quanto este último (Tabela 16).

Não tendo havido correlação entre fósforo solubilizado e $\mathrm{pH}\left(\mathrm{r}^{2}=0,2966\right.$, não significativo $)$, esses resultados podem indicar que o fungo 60 interfere no $\mathrm{pH}$ do meio, pela secreção de metabólitos, visando obter uma faixa de $\mathrm{pH}$ ideal à sua atividade, fisiologicamente distinta. E possivel que isto ocorra para favorecer a atividade enzimática. BAREA et alii, em 1970, admitiram que um mecanismo enzimático poderia estar envolvido no processo, podendo ou não haver a participação de ácidos orgânicos.

Nos experimentos 1 e 2 , quando se utilizou glicose como substrato oxidável, o fungo 60 apresentou um $\mathrm{pH}$ próximo a 3. E neste experimento, os fungos 25 (Penicillium $\mathrm{sp)}$ e 34 (A. niger) causaram elevação do $\mathrm{pH}$ na vinhaça esterilizada, em relação ao controle esterilizado (Tabela 16), ao contrário do ocorrido com o emprego de glicose (experimentos 1,2 e 3). Esta variação de $\mathrm{pH}$ 
relacionada ao substrato está de acordo com os resultados obtidos por EIRA \& CARVALHO, em 1970.

A Tabela 16 mostra que 0 emprego do fungo 25 (Penicillium sp) spromoveu significativa solubilização da fluorapatita na vinhaça esterilizada, o que não ocorreu ao se introduzi-1o na vinhaca natural; e a introdução do fungo 34 (A. niger) nos meios natural e esterilizado não causou solubilização significativa do fosfato de rocha. E possivel que estes fungos sejam incapazes de suprimir supostas relações antagônicas junto à microbiota própría da vinhaça, ou de reduzir o pH deste meio para valores adequados à máxima solubilização da fluorapatita. Não fosse a impossibilidade, neste experimento, de quantificar somente a biomassa dos fungos introduzidos, o estudo desta variável melhor esclarecería o fenômeno.

Os resultados expressos na Tabela 16 sugerem que a autoclavagem impede a elevação do $\mathrm{pH}$ da vinhaça no decorrer do tempo, efeito este minimizado pela introdução dos fungos 60,34 e 25 .

\footnotetext{
${ }^{6}$ Observou-se crescimento nítido de colônias fúngicas em todo os frascos contendo vinhaça natural, inclusive nos frascos-controle.

${ }^{7}$ Resta saber se isto é devido à eliminação da microbiota nativa, a alteraçães químicas, físicas, físicoquímicas dos seus constituintes, ou devidoà interação destes fatores.
} 
73.

\title{
5. CONCLUSÕES
}

\author{
Nas condiçốes em que os experimentos foram \\ conduzidos pôde-se concluír que:
}

1. Houve solubilização significativa da fluorapatita "Fosfino", causada pela atividade de fungos filamentosos introduzidos, nos meios com glicose, vinhaça natural e vinhaça esterilizada.

2. Em meio sintético a atividade solubilizadora dos fungos Aspergillus niger (cultura 34) e Pencillium sp (cultura 25) fol influenciada pela dose de fosfino empregada: aos 21 dias de cultivo A. niger solubilizou aproximadamente 54, $70 \%$ e 100 mais fósforo que Penicillium sp, quando utilizados $0,5,1,0$ e $2,0 \mathrm{~g}$ de fluorapatita por $50 \mathrm{ml}$ de meio, respectivamente. Empregando-se a dose $3,0 \mathrm{~g}$, ambos apresentaram resultados semelhantes em quatro períodos de cultivo. Ao contrário, doses de fosfino não causaram efeito na solubilização da fluorapatita por estes fungos e A. niger cultura 60 em vinhaça esterilizada. 


\begin{abstract}
3. 0 substrato empregado causou alterações na capacidade solubilizadora: fungos considerados bons solubilizadores em melo com glicose pouco ou nada solubilizaram em vinhaça natural, e vice-versa. Os fungos não selecionados, cultivados em meio sintético, também poderiam ter apresentado bons resultados sob cultivo em vinhaça.
\end{abstract}

4. O tempo de cultivo interferiu na atividade solubilizadora, tanto em vinhaça esterilizada quanto em meio sintético, apresentando diferentes resultados, dependendo do fungo. Cultivos prolongados, superiores a 21 dias, promoveram melhor solubilização.

5. Aspergillus niger (cultura 34) em fosfino bruto e meio sintético solubilizou teores de fósforo equivalentes aos causados pelo ataque puramente do $\mathrm{H}_{2} \mathrm{SO}_{4}$ (33 $g / 200 \mathrm{~g}$ fosfino, ou $25 \%$ de solubilização). A atividade fúngica não alterou a composição mineralógica do material.

6. Em meio sintético a solubilização aumentou com a diminuição do $\mathrm{pH}$. Na vinhaça natural e esterilizada não houve correlação entre pH e fósforo solubilizado. 
75.

7. Aspergillus niger (cultura 60), apresentou grande capacidade de se adaptar às diferentes condições ambientais, sendo o único fungo selecionados que solubilizou - fosfino, de modo significativo, em vinhaça natural, reduzindo $0 \mathrm{pH}$ de 8,6 para 6,8 . Em vinhaça estéril causou significativa solubilização do fosfino, elevando 0 pH de 4,2 para 5,5 .

8. Novos estudos in vitro utilizando-se outros fungos, vinhaça de origem diversa, bem como fermentação em média escala e posterior teste de eficiência agronômica do fertilizante líquido, poderiam decidir pela utilidade econômica do processo de solubilização biológica da fluorapatita "fosfino". 
76 ,

REFERENCIAS BIBLIOGRÁFICAS

AGNIHOTRI, V.P. Solubilization of insoluble phosphates by some fungi isolated from mursery seedbeds. Canadian Journal of Microbiology, Ottawa, 16: 877-80. 1970.

ALMEIDA, J.R. o problema da vinhaça em São Paulo. Boletim do Instituto Zimotécnico, Piracicaba (3) 1-24, 1952.

BAHIA FILHO, A. F. C. Fósforo em latossolos do Estado de Minas Gerais; intensidade, capacidade tampão e quantidade de fósforo, fósforo "disponível" e crescimento vegetal. Viçosa, 1974. 69 p. (M.S. - Universidade Federal de Viçosa). 
ASSUMPÇÃo, E. Ação da população microbiana natural de um regossolo do Estado de São Paulo, influenciada pela adição de uma fonte de matéria orgânica, sobre um fosfato natural. Piracicaba, 1981. 39p. (Mestrado - Escola Superior de Agricultura "Luiz de Queiroz" NSP).

BAREA, J. M.; RAMOS, A.;CALLAO, V. Contribucción al estudio "in vitro" de la mineralización bacteriana de fosfatos. Microbiologia Española., Madrid, 23: 257-70, 1970.

BRADDLEY, D. B. \& SIELING, D. H. Effect of organic anions and sugars of phosphates precipitation by iron and aluminium as influenced by $\mathrm{pH}$. Soil Science, Baltimore, 76: $175-9,1953$.

CARVALHo, P. C. T. de; EIRA, A. F.; PELLEGRINO, D. Solubilização quantitativa de fosfatos insolúveis, por algumas espécies dos gêneros Aspergillus e Penicilium. Anais da Escola Superior de Agricultura "Luiz de Queiroz", Piracicaba, 26:173-85, 1969. 
CEREZINE, P. C.; NAHAS, E.; BANZATTO, D. A. Soluble phosphate accumulation by Aspergillus niger from fluorapatite. Applied microbiology and Biotechnology, New York, 29: 501-5, 1988.

EIRA, A. F. Solubilização microbiana de fosfatos. In: Cardoso, E.J.B.N; Tsal, S.M.; Neves, M.C. (Coordenador), SBCS - Campinas - 10 p. (No prelo).

EIRA, A. F. \& CARVALHO, P. C. T. A decomposição da matéría orgânica pelos microrganismos do solo, e sua influência nas variações do pH. Revista de Agricultura, Piracicaba, 45 (1): $15-21,1970$.

EIRA, A. F. \& CARVALHO, P. C. T. Determinação da influência da relação $\mathrm{C} / \mathrm{N}$ na solubilização biológica da Apatita de Araxá, pela microflora do solo. In: REUNIÃo DA SEÇÃO REGIONAL DA SOCIEDADE BOTANICA DO BRASIL, 51, Piracicaba, 1969. 
EIRA, A. F. \& CARVALHO, P. C. T. A fonte de carbono como fator da solubilização de fosfatos naturais pela microflora do solo. In: CONGRESSO BRASILEIRO DE MICROBIOLOGIA, 3., Belo Horizonte, 1971. Belo Horizonte, SBM, 1971. v.3, p. $185-6$.

FIGUEIREDO, M. B. Estudos sobre a aplícação do método de Castellani para conservação de fungos patógenos em plantas. Q Biológíco, São Paulo, 33: 9-13, 1967.

FIGUEIREDO, M. B. \& PIMENTEL, C. P. V. Métodos utilizados para conservação de fungos na micoteca da seção de micologia fitopatológica do Instituto Biológico. Summa Phytopathologica, Piracicaba 1(4): 299-302, dez. 1975.

FOSTER, J. W. \& DAVIS, H. Detection and occurrence of acid producing fungi. Bulletin of the Torrey Botanical Club, Austin, $\underline{76}(3): 174-6,1949$. 
80 .

GLORIA, N. A. \& ORLANDO FILHO, J. Aplìcação da vinhaça como fertilizante. Boletím Técnico PLANALSUCAR, Piracicaba, $\underline{5}(1): 5-38,1983$.

HOAGLAND, O.R. \& ARNON, O.I. The water-culture method for growing plants without soil. Califórnia, Agricultural Experimental Station 1950. $32 \mathrm{p}$.

INSTITUTO NACIONAL DE TECNOLOGIA. NOVAS perspectivas para - tratamento microbiológico do vinhoto. Informativo do INT, Rio de Janeiro, 11(19): 3-8, 1978.

ISHISAKI, E. I. Solubilização da apatita de Araxá por Aspergillus niger utilizando-se vinhaça como meio de cultivo. Jaboticabal, UNESP/Faculdade de Ciências Agrárias e Veterinárias - Campus de Jaboticabal, 1987. 60 p.

KANABO, I. A. K. \& GILKES, R. J. The role of soil pH in the dissolution of phosphate rock fertilizers. Fertilizer Research, Dordrecht 12(2): 165-73, 1987. 
81.

KIEHL, E. J. \& PORTA, A. Análises de $11 \times 0$ e compostos; métodos de amostragem, preparo da amostra, análises, cálculos e interpretação dos resultados analítícos. Piracicaba, ESALQ/Depto. de Solos, 1980. 55 p.

KUBAT, J.; NOVAK, B.; KALINOVA, S. Solubilization of Gafsa rock phosphate by soll microflora. Rostlinna Vyroba, Prague, 33: 1183-8, 1987.

LARSEN, S. Soll phosphorus. Advances in Agronomy, New York, 19: $151-206,1967$.

LEAL, J. R.; AMARAL SOBRINHO, N. M. B.; VELLOSO, A. C. X.; ROSSIELLO, R. O. P. Potencial redox e pH: variações em um solo tratado com vinhaça. Revista Brasileira de Ciências do Solo, Campinas, 7: 257-61, 1983.

LOMBARDI, M. L. C. O. Dissolução de três fosfatos naturais através da atividade microbiológica da oxidação do enxofre. Piracicaba, 1981. 62p. (Mestrado - Escola Superior de Agricultura "Luiz de Queiroz" /SP). 
LOPES, A. S. Solos sob cerrado; características, propriedades e manejo. Piracicaba, Instituto da Potassa e Fosfato, 1983.162 p.

LOW, H. A. \& WEBLEY, D. M. Aplate method for stimating the number of phosphate dissoluing and acid-producing bacteria in soil. Nature, London, 182: 1317-8, 1958.

MALAVOLTA, E. \& NEPTUNE, A. M. L. Increasing the efficiency of utilization of soil and fertilizer phosphorus in the subtropical and tropical agricultural system. Anais da Escola Superior de Agricultura "Luiz de Queiroz", 40(2): $825-63,1983$.

MALAVOLTA, E.; REICHARDT, K.; BITTENCOURT, V. C.; STEWART, J. B. W. \& SARRUGE, J. R. Manual de quimica agrícola; nutrição de plantas e fertilidade do solo. São Paulo, Agronômica Ceres, 1976. 528p. 
MERZANI, A H. Transformaciones microbiologicas de compuestos del fosforo. In: GLOBAL IMPACTS OF APPLIED MICROBIOLOGY, São Paulo, 1973.V. 1, p. 529-42.

MICHOUSTINE, E. N. Processus microbiologiques mobilisant les composés du phosphore dans le sol. Revue d' Ecologie et de Biologie du Sol, Paris, $9(3): 521-8,1972$.

NEVES, M. C. P.; LIMA, I. T.; DÖBEREINER, J. Efeito da vinhaça sobre a microflora do solo. Revista Brasileira de Ciência do Solo, Campinas, $7: 131-6,1983$.

PAUL, N. B. \& SUNDARA-RAO, W. V. B. Phosphate-dissolving bacteria in the rhizosphere of some cultivated legumes. Plant and Soil, Dordrecht, 35: 127-32, 1971.

PAULINO, V. T. \& AZCON, R. Respostas de Centrosema pubescens Lenth. à inoculação de micorriza vesículo-arbuscular e microrganismos solubilizadores de fosfato em meio com fosfatos de rocha. Revista Brasileira de Ciência do Solo, Campinas, 11: 263-7, 1987. 
RAIJ. B. van, BATAGLIA, O.L.: SILVA, N.M. da. Acidez e Calagem no Brasil. Campinas, Sociedade Brasileira de Ciência do Solo, 1983.

RAJAN, S. S. S. Effects of sulfur content of phosphate rock/sulfur granules on the availability of phosphate to plants. Fertilizer Research, Dordrecht, 4: 287-96, 1987.

RAMOS, A.; CALlaO, V.; CARVAlHo. P. C. T. La solubilización de fosfatos por hongos del suelo. Microbiologia Española, Madrid, 21, 23-7, 1968.

RESSELER, H. \& WERNER, W. The contribution of different $P$ fractions to the fertilizing effect of partially acidulated phosphate rocks. In: VOLUFA CONGRESS, 99., Koblenz, 1987. Proceeding. Koblenz, J.D. Saverleinders Verlag, 1987. p. 203. 14. (VOLUFA - Achriftenreihe, 33)

SARRUGE, J. R. \& HAAG, H. P. Análises químicas em plantas. Piracicaba, ESALQ/Depto de Química, 1974. 56 p. 
SATTAR, M. A. \& GAUR, A. C. Dissolution of rock phosphate by rhizosphere microorganisms isolated from Bangladesh soils. Bangladesh Journal of Agriculture, Dhaka, 11(2): $27-34,1986$.

SIMPÓSIO SOBRE FERTILIZANTES NA AGRICULTURA BRASILEIRA, 1984.

SOMOGYI, M. Notes on sugar determination. Journal of Biological Chemistry, Bethesda, 195: 19-23, 1952.

SPERBER, J. I. The incidence of apatite solubilizing organisms in the rhizophere and soil. Australian Journal Agricultural Research, Melbourne, $9: 778-81,1958 \mathrm{a}$.

SPERBER, J. I. Solubition of apatite by soil microrganisms producing organic acids. Austrialian Journal Agriculture Research, Melbourne, 9: 782-7, 1958b.

SPERBER, J.I. Solution of mineral phosphates by soil bacteria. Nature, London, 180: 994-5, 1957. 
SUBRAMANIAN, T. R.; IYENGAR, B. R. V.; RAO, M. H.; PALANIAPPAN, R. Transformation, auxilability and mobilization of applied phosphorus in red soils. Indian Journal of Agricultural Chemistry, Allahabad, 20(1): $49-61,1987$.

VENTURINE FILHO, W. G. Produção de biomassa de Aspergillus orizae utilizando vinhaça como substrato de fermentação. Piracicaba, 1986. 89p. (Mestrado - Escola Superior de Agricultura "Luiz de Queiroz"/USP). 